\title{
Constitutional Showdowns
}

\section{Citation}

Eric A. Posner \& Adrian Vermeule, Constitutional Showdowns, 156 U. Pa. L. Rev. 991 (2008).

\section{Published Version}

http://scholarship.law.upenn.edu/penn_law_review/vol156/iss4/3/

\section{Permanent link}

http://nrs.harvard.edu/urn-3:HUL.InstRepos:12933355

\section{Terms of Use}

This article was downloaded from Harvard University's DASH repository, and is made available under the terms and conditions applicable to Open Access Policy Articles, as set forth at http:// nrs.harvard.edu/urn-3:HUL.InstRepos:dash.current.terms-of-use\#OAP

\section{Share Your Story}

The Harvard community has made this article openly available.

Please share how this access benefits you. Submit a story.

\section{Accessibility}




\section{CONSTITUTIONAL SHOWDOWNS}

\section{ERIC A. POSNER ${ }^{\dagger} \&$ AdRIAN VERMEULE ${ }^{H}$}

Constitutional law and politics is full of (what the headlines call) "showdowns" between and among branches of government. ' When the Democratic Congress began investigating the dismissal of United States Attorneys, congressional committees issued subpoenas and the White House asserted executive privilege to block advisers to the President from being forced to testify. ${ }^{2}$ This is a familiar Washington pattern, which usually ends in a bargained compromise between the legislative and executive branches, but occasionally ends up in a largescale showdown. In the latter case, the result may be litigation that creates a judicial precedent, a political settlement that creates a nonjudicial precedent, or both.

Showdowns occur between the President and the courts, between Congress and the courts, as well as between the President and Congress. Indeed, some showdowns involve all three branches simultaneously, or threaten to do so. When congressional committees issue subpoenas and the executive asserts privilege, the courts may eventually be asked to enforce the subpoenas. When Franklin Roosevelt at-

${ }^{\dagger}$ Kirkland \& Ellis Professor of Law, University of Chicago.

${ }^{\text {t十 }}$ Professor of Law, Harvard Law School. Thanks to David Abrams, Jacob Gersen, Todd Henderson, Daryl Levinson, Adam Samaha, Matthew Stephenson, Cass Sunstein, Jonathan Wiener, John Yoo, workshop participants at the University of Chicago Law School, and participants at a Harvard Conference on Constitutions and Consequences, for helpful comments, and to Jennifer Shkabatur and Elisabeth Theodore for helpful research assistance.

'See, e.g., Edward Epstein, Dems Seek Showdown on War; House, Senate Leaders To Push Legislation That Would Force Bush To Withdraw Troops, S.F. CHRON., Mar. 9, 2007, at A1 (describing proposals by congressional Democrats that would mandate troops leaving Iraq against President Bush's opposition to such measures); Maura Reynolds, Senate Vote Nears on Guantanamo Detainee Rights; Showdown Is Set Today on a Measure That Would Bar Prisoners' Access to Federal Court, L.A. Times, Nov. 15, 2005, at A14 (detailing legislative action to overturn a Supreme Court decision); Reynolds Holding, The Executive Privilege Showdown, TIME.COM, Mar. 21, 2007, http://www.time.com/time/nation/ article $/ 0,8599,1601450,00 . \mathrm{html}$ (describing the right the executive branch claims it has "to withhold certain information from Congress").

${ }^{2}$ See Sheryl Gay Stolberg, Bush Moves Toward Showdown with Congress on Executive Privilege, N.Y. TIMES, June 29, 2007, at A23 (explaining the clash between President Bush's assertion of his "right to unfettered and candid advice from his top aides" and the "Congressional right to conduct oversight"). 
tempted to pack the Supreme Court, the attempt implicated congressional as well as judicial prerogatives, because a bill was necessary to expand the number of seats on the Court. Some legislators opposed the bill even though (they claimed) they would have favored a constitutional amendment. ${ }^{3}$

The idea of a constitutional showdown seems, at first, hopelessly vague. But informal talk of showdowns is extremely widespread and persistent in both scholarship and in the popular press, and there is undoubted pretheoretical appeal to the category, which seems to capture one major mechanism of constitutional development. Our project here is to put some theoretical backbone into the idea of a constitutional showdown. ${ }^{4}$ We attempt to give a usable definition of the idea, analyze the circumstances under which showdowns will or will not occur, and offer some normative observations about whether the American constitutional system tends to produce too many or too few

${ }^{3}$ See Adrian Vermeule, Political Constraints on Supreme Court Reform, 90 MINN. L. REV. 1154, 1170 (2006).

${ }^{4}$ The closest analogue in the literature is the useful idea of "constitutional hardball." See Mark Tushnet, Constitutional Hardball, 37 J. MARSHALl L. REV. 523, 523 (2004) (defining "constitutional hardball" as "political claims and practices-legislative and executive initiatives-that are without much question within the bounds of existing constitutional doctrine and practice but that are nonetheless in some tension with existing pre-constitutional understandings"). Although Tushnet uses some of the same examples we will discuss, Tushnet specifies his idea by reference to preexisting constitutional understandings, while we specify ours by reference to the downstream precedent-setting effects of showdowns. See infra Part I.B. Moreover, Tushnet embeds "constitutional hardball" in a jurisprudential framework structured around Bruce Ackerman's theory of constitutional transformation, whereas we use a standard welfare-economic framework. As for Ackerman, his idea of a "constitutional moment" is a subset of constitutional showdowns; many episodes that count as showdowns under our definition are not constitutional moments in Ackerman's sense. See 1 BRUCE ACKERMAN, WE THE PEOPLE 22 (1991) (describing "concrete historical processes that allowed Americans to transform moments of passionate sacrifice and excited mobilization into lasting legal achievements"). Jack Balkin and Sanford Levinson distinguish between constitutional crises in which actors concede they are violating the Constitution (usually, they claim, in order to save the Constitution), and crises in which actors claim to be acting within the boundaries of the Constitution. See Sanford Levinson \& Jack Balkin, Three Types of Constitutional Crisis (2007) (unpublished manuscript, on file with authors). This is a legal distinction orthogonal to our concept of a showdown, which might fall into either category. (We omit Balkin and Levinson's third category, which is not relevant here.) Finally, there is also a related private-law literature on litigation and settlement. See, e.g., William M. Landes \& Richard A. Posner, Adjudication as a Private Good, 8 J. LeGal STud. 235 (1979) (discussing incentives of individuals to resolve disputes in a socially optimal way); Steven Shavell, The Level of Litigation: Private Versus Social Optimality of Suit and Settlement, 19 INT'L REV. L. \& ECON. 99 (1999) (comparing the socially optimal level of litigation to privately determined levels of litigation). 
showdowns, and whether the showdowns it does produce occur under socially optimal circumstances.

Part I defines showdowns both conceptually and by example and organizes our succeeding claims. Part II examines the social costs and benefits of showdowns. The main benefit is that showdowns clarify the constitutional allocation of powers, reducing transaction costs and uncertainty in later periods or generations. The main costs are that showdowns can produce needless conflict and erroneous or premature resolution of constitutional issues in the current period, given that circumstances and constitutional controversies are constantly changing over time.

Part III argues that the observed rate and distribution of showdowns will in all likelihood diverge from the socially optimal rate and distribution of showdowns. The branches of government and the officials who staff them will produce showdowns when the private benefits exceed the private costs, not when the social benefits exceed the social costs. Although it is not clear, in theory, whether showdowns will be too many or too few, we suggest some institutional reasons for thinking that the American constitutional order produces too few showdowns and too much uncertainty about the allocation of constitutional powers.

In Part IV, we elicit the main normative implication: where the social benefits of clarifying the constitutional allocation of authority for future generations are large, and the countervailing costs of constitutional conflict and erroneous or premature resolution of issues are low, institutions should be encouraged to practice the active virtues as opposed to the passive virtues. ${ }^{5}$ Rather than ducking constitutional conflicts, they should be encouraged-through incentive-based institutional design, public suasion, or other means-to engage in more constitutional showdowns than they would otherwise choose. A brief conclusion follows.

\section{PRELiminaries}

We will define constitutional showdowns both extensionally, by examples and paradigm cases (in Section A), and intensionally, by necessary and sufficient criteria (in Sections B and C). The former

See AleXANDer M. BiCKEL, THE LEAST DANGEROUS BRANCH 111-99 (2d ed. 1986) (describing "the passive virtues" that counsel the Supreme Court against deciding some constitutional questions on the merits). 
procedure is appropriate for family-resemblance complexes, where there are many related ideas that share no single common property or defining feature; the idea of a constitutional showdown doubtless has a family-resemblance structure of this sort. Nonetheless we think it will be useful to the reader to attempt a conceptual definition as well, if only to indicate more clearly where our theoretical concerns lie.

\section{A. Examples}

To motivate the later discussion, and to indicate the sorts of cases we have in mind, consider the following examples of the three major categories of showdowns we will discuss.

\section{Presidential-Congressional Showdowns}

Impeachments are the most dramatic constitutional showdowns, and inevitably create precedents. Andrew Johnson's impeachment for violating the Tenure of Office Act, which forbade presidential removal of certain cabinet officers without congressional approval, was defeated by a single vote; the Supreme Court later cited this episode to support a conclusive constitutional rule in favor of presidential power to remove executive officers, ${ }^{6}$ or at least "purely" executive officers. The Nixon impeachment had a double precedential effect, both creating legal forms that were used in the Clinton impeachment, and provoking a constitutional showdown between Nixon and the Court that itself created a judicial precedent on executive privilege. ${ }^{8}$

Struggles over appointments and executive privilege can, of course, result in constitutional showdowns even where no impeachment eventuates. A pure example of a constitutional showdown occurred when

[o]ne year into President [George H.W.] Bush's term, Congress passed ... a provision prohibiting the United States from spending any money authorized for international conferences on the U.S. delegation to the Conference on Security and Cooperation in Europe unless that delegation included representatives of the Commission on Security and

${ }^{6}$ Myers v. United States, 272 U.S. 52, 176-77 (1926) (holding unconstitutional a law denying the President unrestricted power to remove the postmaster).

'Humphrey's Executor v. United States, 295 U.S. 602, 626-28 (1935) (limiting the Myers decision such that the power of removal did not apply to members of the Federal Trade Commission, a body with legislative and judicial duties).

${ }^{8}$ See generally Akhil Reed Amar \& Neal Kumar Katyal, Executive Privileges and Immunities: The Nixon and Clinton Cases, 108 HARV. L. REV. 701 (1995). 
Cooperation in Europe. This Commission was composed almost entirely of members appointed by the legislative branch.

Given the far-reaching challenge to powers of the presidency, President Bush's response was extremely forceful. He announced that the provision was unconstitutional, and that he would refuse to enforce it ....

... [W] [Wile the House of Representatives' lawyer bitterly complained about the President's refusal to enforce the law, members of Congress took no further action.

\section{Presidential-Judicial Showdowns}

Here too some cases result in a judicial precedent and some do not. In the latter situation, consider Lincoln's decision to defy a habeas corpus order issued by Chief Justice Taney (in Ex parte Merryman) during the opening days of the war. ${ }^{10}$ This counts as a showdown because Lincoln's action was based on a particular view of presidential power to defy the courts in situations of extreme crisis, where doing so is necessary to save "all the laws, but one"; because the judges acquiesced through inaction, and through extreme deference to Lincoln until the end of the Civil War; and because Lincoln's action created a (nonjudicial) constitutional precedent that clarified the constitutional lines of authority and is cited to this day by constitutional theorists with various views of presidential power, judicial power, and the role of emergencies in constitutional law. ${ }^{12}$

The former situation is exemplified by some of the most famous cases in constitutional law, such as the Steel Seizure case, Youngstown Sheet $\mathcal{E}^{2}$ Tube Co. v. Sawyer, ${ }^{13}$ and the Watergate tapes case, United States v. Nixon. ${ }^{14}$ In the former, the Court rejected a claim by President Truman that he had constitutional power to seize steel plants to prevent a

${ }^{9}$ John O. McGinnis, Constitutional Review by the Executive in Foreign Affairs and War Powers: A Consequence of Rational Choice in the Separation of Powers, LAW \& CONTEMP. ProbS., Autumn 1993, at 293, 309-11.

${ }^{10}$ Ex parte Merryman, 17 F. Cas. 144 (C.C.D. Md. 1861) (No. 9487).

"Abraham Lincoln, Message to Congress in Special Session (July 4, 1861), in 4 THE COLLECTED WORKS OF ABRAHAM LinCOLN 421, at 430 (Roy P. Basler ed., 1953) (emphasis omitted).

${ }^{12}$ In addition, consider Andrew Jackson's refusal to comply with the Supreme Court's decision in Worcester v. Georgia, 31 U.S. 515 (1832), which held that Georgia laws had no force in Indian territory.

19343 U.S. 579 (1952).

14418 U.S. 683 (1974). 
work stoppage that would have cut off war material for American forces in Korea; ${ }^{15}$ in the latter, the Court rejected a "generalized" claim of executive privilege and forced Nixon to turn over Oval Office recordings that had been lawfully subpoenaed in a grand jury investigation. ${ }^{16}$ In both cases, the President, unlike Lincoln, promptly acquiesced by obeying the Court's orders, and the cases have set the terms of various separation of powers controversies to the present day.

\section{Congressional-Judicial Showdowns}

A central storyline of American constitutional history involves showdowns between Congress and the judiciary. ${ }^{17}$ As usual, such showdowns have created precedents even when no judicial decision ensued. During Reconstruction, the Republican Congress manipulated the number of Justices in order to deny Democrat Andrew Johnson appointments to the Court, first lowering the number of seats and then raising the number when Ulysses S. Grant came into office. ${ }^{18}$ Congress's actions during this period were a prominent precedent for Franklin Roosevelt's Court-packing plan; the failure of that plan itself set a precedent that weighs against future manipulation of the Court's membership.

Other actions of the Reconstruction Congress did result in judicial precedents. One was to enact legislation that deprived the Court of jurisdiction to hear a pending case, thus preventing the Court-were the legislation upheld-from limiting congressional power to deploy military commissions in the former Confederacy. Bowing to the political winds, the Court upheld the jurisdiction-stripping statute in Ex parte McCardle. ${ }^{19}$ The decision has served as an important precedent in many later episodes and cases; although its authority has been questioned by commentators, ${ }^{20}$ and the Court has in later episodes typically used aggressive statutory construction to find jurisdiction while avoiding the

${ }^{15}$ Youngstown, 343 U.S. at 589.

${ }^{16}$ Nixon, 418 U.S. at 713.

17 See generally CHARLES GARDNER GeYH, WHEN COURTS \& CONGRESS COLlidE: THE STRUGGLE FOR CONTROL OF AMERICA'S JUDICIAL SYSTEM (2006).

${ }^{18} I d$. at $66-67$.

1974 U.S. (7 Wall.) 506, 515 (1868).

${ }^{20}$ Barry Friedman, The History of the Countermajoritarian Difficulty, Part II: Reconsiruction's Political Court, 91 GEO. L.J. 1, 36 (2002) ("Given the odor of politics [at the time of the Court's decision], it is somewhat surprising that the Court's dismissal of $M c$ Cardle frequently has been invoked as support for the proposition that Congress has broad power to remove cases from the jurisdiction of the Supreme Court."). 
constitutional questions, this sort of controversial posthistory is the fate of many prominent precedents, both judicial and nonjudicial.

\section{B. Definitions}

We will say that a constitutional showdown is (1) a disagreement between branches of government over their constitutional powers that (2) ends in the total or partial acquiescence by one branch in the views of the other and that (3) creates a constitutional precedent. ${ }^{21}$ Constitutional showdowns are a subset of legal showdowns generally; the latter would include, for example, a disagreement between the President and the courts over whether the President has been granted particular powers by statute, rather than by constitutional law.

Our definition embodies several assumptions. First, we will often speak of "institutional interests" or the interests of branches of government; these formulations are just shorthand for the point that individuals are in some cases motivated to promote the interests of institutions to which they belong, although in other cases they are not. ${ }^{22}$ We relax this simplifying assumption in later discussion, but for now we will use personified branches-the President, Congress, and the courts. The justification for this assumption is twofold: it simplifies the presentation of our claims without serious loss of accuracy, and each branch contains internal rules for aggregating individual votes

${ }^{21}$ Peter Spiro offers an illuminating treatment of the way in which war powers controversies acquire precedential force.

[T] he legal significance of any such episode will hinge on three elements. First, it is actions that count, not words; mere assertions of executive or legislative authority are largely irrelevant in the long run, the chaff of institutional bravado. Second, in order to take on lawmaking significance, the conduct must be known to the other branch; secret operations will have no constitutional significance until they are made known to Congress and it has had an opportunity to respond. Third, the other branch must have accepted or acquiesced in the action. Any conduct that satisfies (or even arguably satisfies) these requirements will become part of the precedential mix; a single historical episode can create incremental elements of custom in the same way that a single judicial decision will incrementally change court-made doctrine.

Peter J. Spiro, War Powers and the Sirens of Formalism, 68 N.Y.U. L. REv. 1338, 1356 (1993) (book review) (footnotes omitted). Our definition draws on Spiro's but generalizes it to a broader range of constitutional settings.

${ }^{22}$ See Daryl J. Levinson, Empire-Building Government in Constitutional Law, 118 HARV. L. REV. 915, 955 (2005) ("When legislators do find it politically advantageous to take a position,... that position is mostly determined not by the institutional interest of Congress but by the views of their constituents (and, difficult to disaggregate, their own personal policy preferences)."). 
into institutional decisions, such as statutes, judicial precedents, and executive orders. ${ }^{23}$ Likewise, we also bracket the role of political parties in a separation of powers system, and take up that issue in later discussion as well.

Second, we assume that constitutional showdowns create precedents, either judicial or nonjudicial, and that these precedents have some positive force in decision making during later periods. Of course, showdowns are neither necessary nor sufficient to create constitutional precedents, but they have a probabilistic tendency to do so, which is sufficient to motivate our assumption. Subsequently, we discuss alternative mechanisms of interstitial or small-scale change that also create constitutional precedents.

When showdowns create precedents, the force of such precedents may be large or small, depending on circumstances and context. Despite skepticism about the force of both judicial and nonjudicial precedents, our assumption is minimal. Nonjudicial precedents, like judicial ones, are rarely the only consideration that later decision makers take into account and are often overridden or ignored because preferences or political circumstances have changed; but this does not mean the precedents never existed in the first place. "Individual episodes will, of course, have more or less weight in the same way that decisions from some courts are more meaningful than from others, and in this respect such factors as frequency, consistency, and regularity will be important to determining the constitutional probity of a particular practice."

Note that what starts off as a showdown might end as a compromise, with the disagreement papered over and neither side acquiescing at all in the other side's claim to authority. Or the underlying source of dispute might resolve itself before a true impasse is reached. We will, by definitional fiat, decline to call these situations showdowns, albeit with the proviso that the line between a showdown and ordinary mechanisms of constitutional development is a fine one.

${ }^{23}$ See McGinnis, supra note 9, at 295 . Actually, there are two slightly distinct issues here. First, even where a branch is staffed by a single individual, such as the President, there may be a divergence between "the interest of the man" and the "rights of the place." See THE FEdERAlist NO. 51, at 322 (James Madison) (Clinton Rossiter ed., 1961). Second, the branches are staffed by multiple actors and thus face internal problems of aggregation. This is obvious for Congress and the judiciary; it is also true in practice of the executive branch, which includes not only the President but a welter of cabinet officers, agencies, and other entities. For now, we bracket both problems and assume that all branches act like unitary individuals who rationally pursue the branch's objective interests.

${ }^{24}$ Spiro, supra note 21 , at 1356. 
Several mechanisms can cause the settlements that occur in earlier episodes to have positive force in later times. The "civilizing force of hypocrisy" ${ }^{25}$ makes it positively costly for decision makers to disavow a principle they relied on to their benefit at an earlier time, although in some cases the benefits of opportunistic disavowals of precedent are worth the cost. Precedents may create focal points that coordinate behavior; ${ }^{26}$ indeed, focal points can affect behavior even in interactions that mix cooperative and distributive motives ${ }^{27}$ - circumstances where all branches involved want to coordinate, yet the branches have different preferences about which rule or practice to coordinate upon. Precedents reduce the costs of decision making, so that in later periods decision makers may follow them even if they would have preferred a different rule if deciding on a blank slate; more nebulously, precedents set in an earlier showdown tend to ossify into institutional routines and individual habits, and may even become internalized by actors who develop a sense of legal obligation to follow the precedent. We return to this last possibility shortly.

Third, the constitutional "precedent" that is created by a showdown may, but need not, be a judicial precedent. It may also be an unwritten constitutional norm or convention ${ }^{28}$ - a practice that is widely understood as a settlement of a constitutional question and that is regular or stable over time, although it need not be eternal. Constitutional conventions in this sense include the refusal of any president after Washington and before Franklin Roosevelt to stand for a third term, a convention that eventually collapsed, and the norm that the President need not submit treaties to the Senate during the negotiating phase, but need only obtain ex post Senate ratification. The latter practice was also established by Washington but has persisted to the present day. ${ }^{29}$

25 JON ELSTER, ALCHEMIES OF THE MiND 341, 402 (1999).

${ }^{26}$ See Thomas C. SCHElling, THE STRATEgy OF CONFlict 67-68 (2d ed. 1980) (arguing that " $[\mathrm{p}]$ recedent seems to exercise an influence that greatly exceeds its logical importance or legal force" and noting that, in the context of explicit bargaining, the parties tend to reach settlements that align with those previously determined in similar situations, as "often it seems that there is simply no heart left in the bargaining when it takes place under the shadow of some dramatic and conspicuous precedent").

${ }^{27}$ On the role of focal points in the Battle of the Sexes game, see JAMES D. MORROW, GAME THEORY FOR POLITICAL SCIENTISTS 94-97 (1994).

${ }^{28}$ See Jon Elster, Unwritten Constitutional Norms (2007) (unpublished manuscript, on file with authors).

${ }^{29}$ See STANley Elkins \& ERIC MCKitrick, THe Age of Federalism 55-58 (1993) (describing Washington's sole appearance before the Senate concerning a treaty under negotiation and how the resulting confusion confirmed that such consultations 
Fourth, the requirement of acquiescence has a special meaning and theoretical significance. By acquiescence, we will again refer to the observed practice or behavior of the branches, rather than to their official positions. It is common that branches will give in or strike a bargain that effectively acquiesces in the views of another branch, all the while disclaiming any surrender of official powers or intention to set a precedent. Presidents, for example, routinely waive claims of executive privilege, allowing even their closest advisers to testify before Congress, while denying that they have compromised their constitutional prerogatives. ${ }^{30}$ In our definition, such events count as showdowns that have set nonjudicial precedents in favor of the constitutional power of Congress to require testimony from executive officials. Another complication is that acquiescence can be total or partial; one branch might clearly cede to another some, but not all, of what the other branch claims. This does not affect the analysis, but complicates the exposition, so we will usually address only the limiting case.

The theoretical motivation for this behavioral definition of acquiescence is the following. We are interested in legal uncertainty in the American constitutional system. Where a branch has repeatedly acquiesced in practice to the views of another branch, the effective level of legal uncertainty is low even if the acquiescing branch has formally or nominally adhered to its position. Actors will anticipate that the practice will likely, though not certainly, be repeated if a similar controversy arises. In such cases legal uncertainty would be reduced even further if the acquiescing branch had formally knuckled under, abjuring its previous constitutional position; but that reduction will be of marginal importance, at least where the behavior has become regularized. Branches cannot avoid creating precedents just by using magic words. Other actors will adjust their behavior based on their best estimates of how the branch behaves, not just on what it says.

Finally, we will focus on showdowns between or among the three major branches of the national government. However, other actors

were impracticable, though ex post presentation for ratification fit the requirements of both the Constitution and political expediency).

${ }^{30}$ Regarding those alleged prerogatives, see HAROLD C. RELYEA \& TODD B. TATElman, CONG. RESEARCH SERV., PRESIDENTIAL ADVISERS' TESTIMONY BEFORE CON. GRESSIONAL COMMITTEES: AN OVERVIEW 27 (2007), available at http://www.fas.org/ $\mathrm{irp} / \mathrm{crs} / \mathrm{RL} 31351$.pdf ("The range of executive branch officials who may appropriately assert executive privilege before congressional committees, and the circumstances under which they may do so, remains unresolved by the courts and is a matter that may be determined by case-by-case accommodation between the political branches." (citations omitted)). 
engage in showdowns as well. There can be showdowns between political parties, as when the majority and minority parties in the Senate disagree about the extent to which the minority party can block votes, put members on committees, and influence procedural rules. ${ }^{31} \mathrm{~A}$ dramatic example of such a showdown occurred when members of the Texas legislature tried to leave the state in order to prevent a quorum from forming and the majority party tried to have them arrested. $^{32}$ There can be showdowns between sections of the country: the showdown over slavery between the North and the South led to the Civil War. There can be showdowns between the national government and the state governments, as occurred when Orval Faubus, the governor of Arkansas, refused to comply with an order of the Supreme Court, and President Eisenhower deputized the Arkansas National Guard. And showdowns often involve overlapping political divisions, as when a branch controlled by one party reaches an impasse with a branch controlled by another party. In all cases, agents granted political authority by the Constitution disagree about the contours of their authority and refuse to back down in the face of competing claims by other agents.

Our assumption that showdowns can create nonjudicial precedents is related, but not identical, to the idea that customary practices are a source of law. In the theory of international law, customary law consists of practices-behavioral regularities-followed from an internalized sense of legal obligation, or opinio juris. Theorists of domestic constitutional law ${ }^{33}$ and foreign relations law ${ }^{34}$ have adapted opinio juris to identify law that arises from interbranch interactions, such as the President's power to withdraw public land from private acquisition $^{95}$ or to deploy forces abroad in small-scale operations, like the invasion of Grenada, without congressional approval. ${ }^{36}$ All these

${ }^{31}$ We incorporate political parties into the analysis in Part III.C, infra.

${ }^{32}$ See Texas Search for Democrats Is Ruled Illegal, N.Y. TIMES, July 12, 2003, at A7.

${ }^{39}$ See, e.g., Michael J. Glennon, The Use of Custom in Resolving Separation of Powers Disputes, 64 B.U. L. REV. 109, 111-12 (1984) (analyzing the role of custom as "an extratextual source of authority" in resolving disputes concerning the separation of powers).

${ }^{34}$ See Spiro, supra note 21, at 1340 (proposing that, in the law of war powers, "[c] ustom dominates in place of text").

${ }^{33}$ See United States v. Midwest Oil Co., 236 U.S. 459, 469 (1915) (upholding the President's ability to issue such orders as "a long continued practice"). See also Glennon, supra note 33 , at $115-16$, for a further discussion of the role played by custom in the Court's reasoning.

${ }^{36}$ See Spiro, supra note 21, at 1356 (maintaining that while, when viewed in isolation, "congressional acquiescence in the invasion of Grenada may have been of mid- 
theorists deploy the idea as a criterion for winnowing law out of the larger set of behavioral regularities or governmental practices; the idea is that some behavioral regularities, such as the practice that nations send diplomats to the funerals of past heads of state, or the practice of Supreme Court justices attending the State of the Union address, are not felt by the actors themselves to have any legally obligatory character and thus cannot count as law.

For our purposes, however, opinio juris is a sufficient but not a necessary condition for showdowns to have precedential force. All that matters is that showdowns create some sort of precedential constraint that enters into the decisions of subsequent actors, whether or not it is decisive (just as judicial precedents might or might not be decisive, but are always relevant). One way that positive precedential force might arise is that actors internalize and take to be legally obligatory the practices of the past, but there are other mechanisms that also give rise to precedential force, as we have mentioned. Precedents may just be patterns of behavior that parties recognize as providing focal points that permit cooperation or coordination. ${ }^{37}$ Under the civilizing force of hypocrisy, actors will incur a cost if they act too opportunistically in disavowing earlier positions whenever it suits their interests, and this cost will affect their later decisions. But that does not require-indeed it implicitly denies-that the actors have internalized the earlier practices as legally obligatory.

\section{Authority, Policy, and Public Opinion}

Here we clarify some elements of our definition, particularly the condition that actors must disagree about the allocation of constitutional authority. Showdowns occur when the location of constitutional authority for making an important policy decision is ambiguous or contested, and multiple political agents (branches, parties, sections, governments) have a strong interest in establishing that the authority lies with them. Although agents often have an interest in negotiating a settlement, asymmetric information about the interests and bargaining power of opposing parties will sometimes prevent such

dling significance," when "added to dozens of similar cases spanning almost the full length of American history, it served to confirm the President's capacity to undertake such incursions without prior legislative approval").

${ }^{37}$ See infra Part I.C. For the argument that this is indeed the appropriate interpretation of opinio juris in international law, see JACK L. GOLDSMITH \& ERIC A. POSNER, THE LIMITS OF INTERNATIONAL LAW 23-43 (2005). 
a settlement from being achieved. The result is a showdown. Ultimately, however, someone must yield; this yielding to or acquiescence in the claimed authority of another agent helps clarify constitutional lines of authority, so that the next time the issue arises, a constitutional impasse can be avoided. From a normative standpoint, constitutional showdowns thus have an important benefit, but they are certainly not costless. As long as the showdown lasts, the government may be paralyzed, unable to make important policy decisions, at least with respect to the issue under dispute.

\section{Preliminaries}

We begin by examining a simplified version of our problem, one involving just two agents-Congress and the executive. We assume for now that each agent is a unitary actor with a specific set of interests and capacities. We also assume that each agent has a slightly different utility function, one that reflects its separate set of constituents. If we take the median voter as a baseline, we might assume that Congress is a bit to the left (or right) of the median voter, while the President is a bit to the right (or left). We will assume that the two agents are at an equal distance from the median, and that the preferences of the population are symmetrically distributed, so that the median voter will be indifferent between whether the President or Congress makes a particular decision, assuming that they have equal information. ${ }^{38}$ But we will also assume that the President has better information about some types of problems and Congress has better information about other types of problems, so that, from the median voter's standpoint, it is best for the President to make decisions about the first type of problem and for Congress to make decisions about the second type of problem. ${ }^{39}$

${ }^{38}$ We do not mean to imply that the expected policy choice will be the median voter's ideal policy choice; we assume that the optimal institutional allocation of authority minimizes the deviation from the median voter's preferences relative to other institutional arrangements.

${ }^{39}$ In setting up the problem in this way, we exclude the possibility that one or both agents would prefer not to have authority over a particular issue because the issue is highly sensitive and politically dangerous. Such an assumption underlies some theories, such as the theory of the "regulatory lottery," according to which Congress grants power to agencies in order to avoid having to make a politically sensitive decision. See Peter H. Aranson, Ernest Gellhorn \& Glen O. Robinson, A Theory of Legislative Delegation, 68 CORNELL L. REV. 1, 7 (1982). We have criticized this view in earlier work. See Eric A. Posner \& Adrian Vermeule, Interring the Nondelegation Doctine, 69 U. CHI. L. REV. 1721, 1746-47 (2002). Because we cannot think of historical examples where two 
Suppose, for example, that the nation is at war and the government must decide whether to terminate the war soon or allow it to continue. Congress and the President may agree about what to do, of course. But if they disagree, their disagreement may arise from one or both of two sources. First, Congress and the President have different information. For example, the President may have better information about the foreign policy ramifications of a premature withdrawal, while Congress has better information about home-front morale. These different sources of information lead the executive to believe that the war should continue, while Congress believes the war should end soon. Second, Congress and the President have different preferences because of electoral pressures of their different constituents. Suppose, for example, that the President depends heavily on the continued support of arms suppliers, while crucial members of Congress represent districts dominated by war protestors. Thus, although the median voter might want the war to continue for a moderate time, the President prefers an indefinite extension while Congress prefers an immediate termination.

So far, we have explained why the President and Congress might disagree about when to terminate the war, but mere policy disagreement does not result in a showdown. Showdowns arise only when there is a disagreement about authority. If Congress believes that the President has the sole authority to terminate the war, then the President's view will prevail. Congress may try to pressure or influence him by offering support for other programs desired by the President or by trying to rile up the public, but these activities are part of normal politics and do not constitute a constitutional showdown. Similarly, if the President believes that Congress has the sole authority to terminate the war, then Congress's view will prevail. This outcome is shown in cell (3) in Table 1. Similarly, no showdown occurs when the two branches agree both about authority and policy-for example, if the President decides and Congress agrees with his decision (cell (1)). The first column represents the domain of normal politics.

branches have tried to slough authority over an issue to each other, we think that this concern can be safely ignored. For the contrary view, see Levinson, supra note 22, at 937 (arguing that accretion of powers by a government entity is not necessarily a driving motive). 
Table 1: Congressional-Presidential Showdowns

\begin{tabular}{|c|c|c|}
\hline & $\begin{array}{c}\text { Agreement } \\
\text { About Authority }\end{array}$ & $\begin{array}{c}\text { Disagreement } \\
\text { About Authority }\end{array}$ \\
\hline $\begin{array}{c}\text { Agreement } \\
\text { About Policy }\end{array}$ & (1) No Showdown & (2) Possible Showdown \\
\hline $\begin{array}{l}\text { Disagreement } \\
\text { About Policy }\end{array}$ & (3) Acquiescence & (4) Showdown \\
\hline
\end{tabular}

Showdowns arise only when Congress and the President disagree about who decides. Here, there are two further possibilities. First, Congress and the President disagree about who decides but agree about the correct policy outcome (cell (2)). In these situations, which arise with some frequency, the two branches are often tempted to paper over their differences because an immediate policy choice is not at stake. But sometimes a showdown will occur. We will discuss this special case in Part II.B. Second, Congress and the President disagree about the policy outcome and about authority (cell (4)). In this case, showdowns are likely because a policy decision must be made, and if the parties cannot agree about what it should be, then they cannot avoid resolving the question of authority. We focus on this case for now.

\section{Why Showdowns Occur}

In our war example, Congress and the President disagree about when the war should end and who should make the decision. Let us suppose that they can both make reasonable constitutional arguments and that the judiciary will not step in to resolve the dispute. What happens next? If each branch asserts its power, we have a full-blown constitutional crisis. No ordinary political or legal means exists for resolving the dispute. Consider how this crisis might play out. One possibility is that Congress enacts a law declaring the war at an end, and the President directs the military to disobey the law. The military would need to decide whether to obey the President or Congress. The military might make this decision on the basis of a good-faith legal analysis, or it might not. Whether or not it does, there is a further question of whether soldiers would obey the decisions of the generals and whether the public would support the decisions of the soldiers. The soldiers might fear that if the generals take an unlawful stance, the soldiers might subsequently be found guilty of committing crimes. And even if they do not, they might fear that the public might fault them for obeying (or disobeying) the generals. A great deal of delay 
and paralysis could result as people decide for themselves what they ought to do. But eventually only two outcomes are possible. One is that the nation divides into factions and a civil war erupts-a real possibility in many countries, but one sufficiently remote in the United States today that we can safely ignore it. The other is that, through the mysterious process by which public opinion forms, the public will throw its weight behind one branch or the other, and the branch that receives public support will prevail.

We will call the public's decision about the location of constitutional authority "public constitutional sentiment." The "public" here does not necessarily mean a fair aggregation of the views of all citizens; it is a stand-in for the complex process by which the views of elites, interest groups, ordinary citizens, and others ultimately determine the de facto lines of political authority-views that might be mediated, or not, by good-faith interpretation of relevant texts and traditions. Nor does "the public" refer to an episodic or superficial political fancy, such as what can be read off a public opinion poll. If a showdown occurs and the government is paralyzed, then the public, or at least important groups, will rouse themselves to attention, and so the view that prevails will reflect more fundamental, quasiconstitutional instincts than the views that prevail in ordinary politics. We will generally assume that public constitutional sentiment is exogenous-determined by social and economic trends and thus not directly controlled by political agents-but it is possible that public constitutional sentiment is also influenced by earlier constitutional showdowns and settlements, given the powerful role of tradition and precedent in public thinking.

Public constitutional sentiment is the bedrock, but that does not mean that it will be profound or even intelligent. There is no reason to believe that public constitutional sentiment actually reflects the optimal allocation of authority: it may be that public constitutional sentiment is simply uninformed, or is heavily influenced by the private interests of groups or elites. It might be that social welfare is maximized if Congress has the authority to terminate the war, but public constitutional sentiment nonetheless places that authority with the President. Our focus is not on whether public constitutional sentiment is optimal but what, given that sentiment, is the optimal way for Congress and the President to act. We will bracket the possibility that Congress and the President may care sufficiently about the public interest to cooperate in allocating powers and avoid impasses that would be resolved by public constitutional sentiment, while still knowing that public constitutional 
sentiment is uninformed and bad for the country. This possibility is not absurd: it is reflected in the views of people who oppose proposals for constitutional conventions because of the risk that the Constitution that emerges would be worse than the Constitution that we have. However, if Congress and the President can maintain such an allocation of powers voluntarily, then, by definition, showdowns do not occur. Thus, we can ignore this possibility for purposes of our discussion.

If public constitutional sentiment will ultimately settle the question of whether Congress or the President has the power to terminate the war, why do showdowns occur? One might think that Congress and the President will simply resolve their dispute by consulting public constitutional sentiment. The alternative would only be a showdown that would last long enough to rouse the public, and the paralysis of government during this interval could damage both the President and Congress and ruin the electoral chances of their occupants.

The question is a familiar one in the game theoretic literature on bargaining, and we adopt that literature's findings. ${ }^{40}$ Game theorists would treat the problem in the context of a standard bargaining game between two agents over a pool of resources or a "pie" whose value declines over time as the agents haggle. When two agents bargain over an asset, the eventual outcome is determined by the parties' valuations of the asset, their relative bargaining power, and the degree of information asymmetry.

Generally speaking, the asset will end up in the hands of the party who values it more. If a seller owns an asset and a buyer values the asset more than the seller does, then a sale will occur and, all else equal, they will split the surplus-the price will be midway between the seller's valuation and the buyer's valuation. If another buyer offers the seller a price higher than the seller's valuation but lower than the first buyer's valuation, then the seller now has an outside option that improves her bargaining position vis-à-vis the first buyer, and hence the agreed-upon price will rise. The price will also reflect inside options, such as the value that the seller receives from using the asset while bargaining proceeds.

Bargaining power refers to the relative time preferences of the agents. If bargaining is likely to take a great deal of time and the seller values future payoffs more than the original buyer does, the seller will be able to hold out for a still higher price. The reason is that the seller

40 See generally ABHINAY MUTHOO, BARGAINING THEORY WTTH APPLICATIONS (1999). We simplify considerably. 
loses less than the buyer as a result of delay caused by a bargaining impasse, and so the buyer will pay a higher price to avoid the delay.

Information asymmetry exists when one or both agents lack information about the valuation of the other. Information asymmetry is always a matter of degree. At one extreme, in a purely theoretical world where information asymmetry does not exist, the agents would come to an agreement in the first round of bargaining because they can only become worse off from delay. As the degree of information asymmetry increases, however, agents might gain an advantage from delay. For example, suppose that the seller does not know whether the buyer values the asset a great deal or very little. If a great deal, the seller would charge a high price; if very little, the seller would charge a low price. Not knowing which buyer she faces, the seller might offer a high price. The high-value buyer would accept the price in order to avoid the cost of delay, while the low-value buyer would hold out an extra round. In the second round, the seller knows that only the lowvalue buyer would have turned down the initial offer and, accordingly, lowers the price. Thus, in equilibrium, delay and the resulting loss of value of the asset occurs with some probability.

The "asset" in our example is the right to determine when the war will be terminated. Congress and the President may value this asset to a different degree, simply because the relevant officials' electoral prospects depend to a different degree on the outcome of the war. One source of asymmetric information, then, arises from uncertainty that each agent may have about the other agent's valuation of the right. ${ }^{41}$ Another source of asymmetric information arises from uncertainty about public constitutional sentiment, and each agent might have different views about the probability that public constitutional sentiment will favor its claim. If the President announces that he will refuse to obey a statute that terminates the war, even if the government will collapse, he is making a strong statement that he values the right to terminate the war a great deal. This statement may or may not be credible; all of this depends on how much Congress knows about the President's incentives. But if the President really does value the right a great deal, and Congress does not believe him, then a long time will pass before a resolution is achieved.

It should be immediately clear that a showdown is a matter of degree. After Congress passes the law declaring the end of the war, the

41 The institutions are aggregations, of course, which complicates this argument; we address this issue in Part III.C, infra. 
executive branch might engage in some tentative actions designed to gauge public constitutional sentiment. It might begin by expressing some reservations about Congress's authority or leaking unofficial statements of disagreement. If the public responds favorably, the executive might take a strong stance, and, correlatively, Congress might back off. If the public's views are ambiguous, both sides might dig in their heels. In the meantime, the military might temporize, hoping for a political resolution. As time passes, the fact of an impasse will become clear, the cost from delay will increase, and an atmosphere of crisis may develop. At some point, one side or the other will back down, a compromise will be achieved, or there will be a breakdown in authority, such as civil war.

The agent that prevails gains two benefits. First, its policy view will prevail. The war will or will not be terminated. Second, its authority over the policy domain will be established in the following sense. When the issue arises again in the future-in some future war, where the President and Congress have different views as to the timing of withdrawal-the institution that made the decision earlier will have presumptive authority to make the decision the second time. The reason is that the first decision will establish that public constitutional sentiment confers authority on that agent. If the President prevails the first time around, then Congress will fear that resisting the President the second time will lead to defeat yet again. To be sure, public constitutional sentiment could shift in the intervening period, but this is only a possibility, and if general political conditions do not change in the meantime, then it is unlikely that public constitutional sentiment will either. Adding to this, the precedent itself might feed into and strengthen public constitutional sentiment, as people generally give weight to tradition and precedent, and the agent who resists the precedent might be faulted for carelessly provoking a crisis. ${ }^{42}$

Our picture, then, depicts political agents being tempted to advance their authority at the expense of other agents, while also fearing that if the other side does not back down, a politically damaging impasse or crisis could occur. Such a crisis would hurt both sides that participate in it, weakening them relative to other agents that stay on

${ }^{42}$ In imaginable cases, an agent will lose the policy battle but win the authority battle. For example, a President might strike a deal with Congress that provides that the President will change policy and Congress will, by some explicit act, recognize the President's authority. But this is not really a case of constitutional change through a showdown; it is a kind of incremental constitutional evolution that occurs through normal politics. 
the sidelines, but one side will emerge with public constitutional sentiment on its side and thus do better than the other side. To avoid showdowns, the agents attempt to predict public constitutional sentiment and reach a bargain, but they sometimes fail. Part II will examine constitutional showdowns from the demand side, asking what rate and distribution of showdowns would be best from the standpoint of social welfare. Part III will turn to the supply side, asking whether national lawmaking institutions will produce or approximate the optimal level and distribution of showdowns. We attempt throughout to state the conditions under which showdowns are welfare improving and the conditions under which decentralized interaction among branches will or will not produce welfare-improving showdowns.

\section{NORMATIVE EVALUATION}

Often the struggle to establish constitutional authority overshadows the decision itself. Showdowns are played for high stakes, and if the benefits are great, the risks are great as well. If both agents take an aggressive stance, then a showdown occurs, and rather than establishing policy and seeing its choice vindicated, each agent finds itself in a costly and protracted battle to assert its authority. The delay and crisis that result can seriously harm the public interest. In Part III, we will discuss how agents' incentives to make these tradeoffs might cause a deviation from the socially optimal outcome. In this Part, we want to establish what that socially optimal outcome is.

\section{A. Social Costs and Benefits}

In the framework on which we have been relying, what are the social costs and benefits of showdowns? The benefit is that a showdown clarifies constitutional authority, reducing decision costs for the government and public in the future. The cost is that a showdown interrupts governance. The social desirability of a particular showdown depends on the balance of this benefit and cost.

Clarification of constitutional authority provides major benefits to the public. When public officials do not know who has the authority to perform some action, they make inconsistent decisions or fail to decide, leaving subordinates uncertain how to proceed and the public confused about law and policy. The public, unable to predict how the government will act, is likely to be excessively cautious. Future generations and current actors-officials, citizens, and litigants-benefit from clarification of the rules of the constitutional game, all else 
equal. Obviously an actor might prefer uncertainty to clearly bad rules, but only if the uncertainty creates a chance that the rules will eventually be clarified in the actor's favor. At any given level of (expected) goodness or badness of the rules, clarity is better than lack of clarity. Furthermore, a risk-averse actor might prefer a clear rule that is somewhat unfavorable, if an ambiguous rule with a more favorable expected outcome carries with it a risk of severe downside loss. And two risk-averse parties may both prefer a compromise that clearly gives them only half a loaf, if there is a chance that uncertainty will eventually be resolved by giving the other party the whole loaf.

Uncertainty is bad to the extent that actors do not like to bear risk, but another problem with uncertainty is that it creates unnecessary transaction costs. In area after area of constitutional law, the precedents, judicial and nonjudicial, created by earlier showdowns are picked over by commentators and the actors involved; but there are relatively few precedents, so they leave open most of the fighting issues, and the resulting debates are interminable and socially fruitless. The only way for the government to act when officials disagree about their authority is through constant negotiation and renegotiation, so officials can trade off favored areas of authority or find common ground where one can act without undermining the goals of the other. An early showdown can reduce this costly wheel-spinning in future generations.

The cost of a showdown is simply that the government does not act-or, more precisely, that the energy of government officials is diverted from the problem at hand to the problem of asserting authority (in the case of top officials) or the problem of ascertaining the lines of authority (in the case of subordinate officials). Top officials stop arguing about whether the war should be terminated-a question involving difficult judgments about troop strength, home-front morale, and so forth-and start arguing about who should have the authority to terminate the war-a question involving difficult judgments about relative institutional advantage in conducting wars. Subordinate officials, like generals and soldiers, must make predictions about how the argument between top officials will be resolved. If they guess wrong, they could find themselves in trouble for disobeying the institution that ends up winning the showdown, or, if they temporize, failing to be prepared when the decision is made. Subordinate officials might end up acting excessively cautiously, so as to avoid offending the different authorities, or allowing policy and military judgments to be influenced by their implications for the resolution of the conflict about 
authority, to the extent that subordinate officials have preferences regarding such resolution. And a showdown over one issue, like executive privilege, might metastasize, as each side refuses to cooperate in other policy dimensions (appointments, budgets, and other areas of substantive legislation) until the other side backs down with respect to the original source of dispute.

Closely bound up with these considerations is that of timing. Often showdowns should be avoided today because they may produce future benefits that are not as great as they might first appear. ${ }^{43}$ There are two advantages from delaying a showdown to the future. First, the particular problem that gives rise to the impasse today might not recur, or might recur only with low probability. If so, the costly shutdown of the government today will turn out to generate a low expected benefit in the future. Second, a resolution today might be erroneous (as judged by the public sentiment of future generations), whereas the particular problem that gives rise to the impasse today might be better understood in the future. Another set of wars might teach the public the advantages and disadvantages of giving the termination authority to the President or Congress; if so, then it might be better to put off establishing the rule until this information has been obtained. This scenario assumes, as always, that the information influences public constitutional sentiment, for a rule once established might be difficult to change. In sum, avoiding a showdown today has an option value equal to the benefit from obtaining additional information before making an irreversible or difficult-to-change settlement that might be erroneous.

To understand these points, consider two examples. First, to continue with our war example, let us further assume that everyone agrees that the United States will continue to enter new wars, routinely, far into the future. Second, consider the Bush/Gore electoral dispute, which occurred because of an unusual confluence of factors that resulted in ambiguity about which candidate had won a single state whose electoral votes were decisive for the election. Imagine that such an outcome is a once-in-a-century event.

It seems clear that resolving the question of war-termination authority is more important for the future than resolving the question of who has the authority to declare the victor in a presidential campaign

49 This is a point about option value. See AVINASH K. DIXIT \& ROBERT S. PINDYCK, INVESTMENT UNDER UNCERTAINTY 135-74 (1994) (outlining formal methods of option valuation). 
that turns on a single state's electoral votes, where the popular vote is so close that minor voting irregularities obscure the outcome. This is not because terminating wars is more important than resolving contested elections. The importance of the policy outcome could be the same as far as we are concerned. The reason that resolving the question of war-termination authority is more important is just that this question will arise many times in the near future. Thus, the shortterm cost of failing to resolve that question without delay for the war today could well be lower than the long-term benefit of having an answer ready when that question arises repeatedly over the next twenty years. ${ }^{44}$ By contrast, the short-term cost of failing to resolve the election without delay today may well be higher than the long-term benefit of failing to resolve similar electoral disputes in the future, simply because the likelihood of similar electoral disputes is so small. The relative importance of the issue is not a factor, because it appears both on the cost side of the equation and on the benefit side of the equation.

Another relevant factor is how much the interests of future generations should be weighted. At one (implausible) extreme, one might think that the interest of future generations should be ignored, in which case showdowns should always be avoided because the benefits accrue only to the future. A more plausible position is that the interests of future generations deserve the same weight as those of the present, in which case showdowns will generally have great value. We take no position in this debate. ${ }^{45}$ Our argument is only that the greater the proper weight for the interests of future generations, the greater the value of showdowns today.

In sum, the optimal outcome can be described in the following way. Suppose that an agent asserts control over a policy area. Another agent should acquiesce if it believes the first agent does in fact have that authority, rooted in public constitutional sentiment. If it does not believe the first agent has such authority, then it should acquiesce only if it believes the long-term gains from a showdown that leads to a clarification of constitutional authority are less than the short-term costs from delay, including the diversion of government resources and the lost option value that results from a premature and possibly erroneous decision that does not exploit future information

${ }^{44}$ Cutting in the other direction, if wars occur more frequently, then the government and the public can learn more about them by putting off the showdown.

${ }^{45}$ For various views on intergenerational equity, see the essays collected in DISCountinc and InTERGenerational Equity (Paul R. Portney \& John P. Weyant eds., 1999). 
or that freezes authority despite changing circumstances. Otherwise, the agent should assert its authority and provoke such a showdown.

This tradeoff will work in favor of causing constitutional conflict when future payoffs are discounted only a little, the particular policy question is likely to recur with high frequency, and little in the way of new information can be expected to arise in the future. A counterintuitive implication of this argument is that a well-run government, one that takes account of the interests of future generations, will find itself in more constitutional conflicts than a poorly run government, holding constant the clarity and completeness of the de jure constitution.

We must also compare the costs and benefits of showdowns with the costs and benefits of alternative means for clarifying the constitutional rules. Showdowns are compressed dramas that occupy the foreground, but in the background is the ordinary slow development of the constitutional order, in which small disagreements, concessions, and adjustments accumulate over time to settle the distribution of powers. If these incremental processes produce an optimal level of constitutional clarity, constitutional showdowns might be all cost and no benefit, and the optimal number of showdowns might be zero.

However, there are some constitutional clarifications that cannot even in principle be produced by small steps; rather, they require sharp breaks with the past. The ultimate constitutional showdown, the Civil War, could not have been replicated by small steps within the preexisting constitutional order; the very point was to settle what that order would be. Likewise, there can be no incremental analogue of the New Deal Court-packing episode, which was by its nature a discrete attempt to change the very structure of the Court all at once, rather than simply to influence its members' preferences through a gradual series of judicial appointments over time (a strategy that Roosevelt also pursued, with far greater success).

This point is often made in the context of evolutionary decision making. Incremental steps are easier than top-down planning, but they can only take one up to a local maximum, which, in any reasonably complex environment, is unlikely to be the global maximum. ${ }^{46}$ The antebellum period was one of incremental compromises that led to a constitutional settlement that, at least in the eyes of the North, was far below a global maximum that could not be reached through a further small step. Other possible examples are easy to think of. The executive branch has become powerful through a large number of in-

${ }^{46}$ See, e.g., JO̊RGEN W. WEIBULL, EVOLUTIONARY GAME THEORY 55-58 (1995). 
cremental steps stretching back two centuries. These steps have led to what some people believe is an excessive concentration of power in the hands of the President. ${ }^{47}$ Whether this belief is correct or not, this type of gradual evolution could not have achieved what is arguably the global peak of executive power-the type of parliamentary system enjoyed by the United Kingdom. This type of change would have required an abrupt switch to an entirely different system.

Furthermore, even where incremental processes are a possible substitute for showdowns, and even where the two mechanisms produce the same eventual level of constitutional clarity, they have a different cost-benefit mix. Incremental processes reduce the direct costs of conflict in the current period-no large-scale political battles are required-and allow a mid-course correction if circumstances change or new information emerges, but they also stretch out low-level conflict over time, with higher interim uncertainty. The same variables we have mentioned determine the conditions under which one process or the other will prove superior: where a clarifying conflict in the current period would be very costly and might produce an erroneous outcome, where the costs of interim uncertainty are low, and where the benefits of keeping options open over time are high, incremental processes should be preferred, but not if conditions are the reverse. Sometimes one set of conditions will hold, sometimes the other. In general, there is no reason to think that incremental processes will always be superior, or that the optimal level of showdowns is indeed zero.

\section{B. The Problem of Ambiguous Acquiescence}

In many historical cases, Congress and the President agree about the policy outcome but disagree about lines of authority. For example, suppose that the executive branch has made a controversial decision, and a suspicious Congress wants the relevant executive officials to testify about their role in that decision. The President believes that Congress has no right to compel the officials to testify, whereas Congress believes that it has such a right. However, the President, in fact, does not mind if the officials testify because he believes that their testimony will reveal that the decision was made in good faith and for good reasons.

${ }^{47}$ See, e.g., LOUIS HENkIN, FOREIGN AFFAIRS AND THE CONSTITUTION 37-65 (1972) (discussing the expansion of presidential power through the lens of relations with other nations). 
The President's problem is that, if he allows the officials to testify, Congress and the public might interpret his acquiescence as recognition that Congress has the power to force executive officials to testify. If he refuses to allow the officials to testify, then he preserves his claim of executive privilege but loses the opportunity to show that the decision was made in good faith. In addition, he risks provoking a constitutional impasse in which Congress could eventually prevail-if, as we have discussed, public constitutional sentiment turns out to reject executive privilege in these circumstances. Congress faces similar dilemmas, for example, when it approves of officials nominated by the President for an agency or commission but wants to assert the power in general to impose restrictions on appointments.

Political agents have long relied on a middle way to avoid the two extremes of acquiescence, on the one hand, and impasse, on the other. They acquiesce in the decision made by the other agent while claiming that their acquiescence does not establish a precedent. Or, equivalently, they argue that their acquiescence was a matter of comity rather than submission to authority. Are such claims credible? Can one avoid the precedential effect of an action by declaring that it does not establish a precedent-in effect, engaging in "ambiguous acquiescence"?

The answer to this question is affirmative as long as the alternative explanation for the action is in fact credible. If, for example, observers agree that the President benefits from the testimony of executive officials, then his acquiescence to a congressional subpoena has two equally plausible explanations: that he independently benefits from the testimony, or that he believes that public constitutional sentiment rejects executive privilege. The response is thus ambiguous, and Congress may be no wiser about what will happen in the future when the President does not wish to permit officials to testify because their testimony would harm him or executive branch processes. If so, the ambiguous nature of the action does not establish a focal point that avoids an impasse in the future.

On the other hand, if the President's claim that he benefits from the testimony is obviously false, then his authority will be accordingly diminished. This is why ambiguous acquiescence is not a credible strategy when the President and Congress disagree about the policy outcome. If the President thinks the war should continue, Congress thinks the war should end, and the President acquiesces to a statute that terminates the war, then he can hardly argue that he is acting out of comity. He could only be acting because he lacks power. But an agent can lack authority in more complicated settings where no seri- 
ous policy conflict exists. If the President makes officials available for testimony every time Congress asks for such testimony, and if the testimony usually or always damages the President, then his claim to be acting out of comity rather than lack of authority eventually loses its credibility. Repeated ambiguous acquiescence to repeated claims over time will eventually be taken as unambiguous acquiescence and hence a loss of authority. For this reason, a President who cares about maintaining his constitutional powers will need to refuse to allow people to testify even when testimony would be in his short-term interest.

From a normative perspective, ambiguous acquiescence reflects a midway point between the extremes of showdown and acquiescence and reflects the same tradeoff. As we saw, agents should tolerate impasse when an issue is of great importance to the future and the cost of present delay is relatively low, and they should avoid impasse in the opposite case. Thus, ambiguous acquiescence is optimal in the middle case: when the issue is of moderate importance to the future and the cost of present delay is moderate as well. It also bears reiterating that ambiguous acquiescence is not always possible; when it is not, then the choice must be acquiescence or confrontation.

\section{The Analogy to Rules and Standards}

Many arguments in legal theory are at bottom arguments about rules and standards. Rules minimize decision costs because the decision maker needs to take account of only a few of the factors that are relevant to the first-best resolution of the dispute, but by the same token they result in predictable error. If decision makers are highly competent, standards avoid error because they permit all relevant factors to be considered, but they involve enormous decision costs. If decision makers are of limited competence, the larger set of information that the standard makes relevant can overload their capacities, perhaps even inducing greater error than under a rule. The optimal choice between rules and standards trades off decision and error costs across contexts. ${ }^{48}$

Our argument reflects a second-order, temporal version of this tradeoff. Constitutional showdowns convert standards into rules that in turn reduce decision costs for future conflicts. A constitutional standard allocates authority in an ambiguous fashion ("the public in-

${ }^{48}$ See, e.g., Louis Kaplow, Rules Versus Standards: An Economic Analysis, 42 DUKE L.J. 557 (1992) (weighing factors in the choice between rules and standards, focusing on whether it is more efficient to allocate content-formation costs ex ante or ex post). 
terest" and the like) that leaves political actors and the public a great deal of work in hashing out the actual allocation when a dispute over authority arises. Agents can avoid establishing a precedent by agreeing early in the process to allow one agent to make the decision or leave authority ambiguous if the agents can agree on a policy outcome. The standard remains in place, and decision costs are thrown onto the shoulders of future agents. However, if the agents instead assert their opposing claims and force a showdown, then a rule may emerge, one that saves decision costs in the future.

The second-order decision, ${ }^{49}$ whether to convert a standard into a rule or allow the standard to remain in place, is akin to a decision to make an investment. An investment involves a cost today, and a return in the future. The cost of the showdown is the interruption of governance; the benefit is the reduced uncertainty for the future-the transformation of a standard into a rule. When judges, legislators, codifiers, restatement drafters, and others come up with rules, we tend to congratulate them for simplifying decision making for future agents. When they maintain standards, we criticize them for failing to clarify the law. But the law should not always be clarified; much depends on whether the law in question will govern many or few actions in the future. At a constitutional level, the decision to have a clarifying showdown or not reflects a similar calculus.

\section{The Judiciary}

So far we have focused on Congress and the executive, for the sake of simplicity. Constitutional confrontations often involve the judiciary as well, as in the examples noted in the introduction. Executive-judiciary impasses occur when the executive refuses to comply with a judicial order, as when Lincoln rejected Justice Taney's grant of Merryman's writ of habeas corpus. ${ }^{50}$ Congress-judiciary impasses are usually less dramatic because Congress lacks executive power, and if the executive refuses to obey judicial orders, Congress can respond only by confronting the executive, rather than the judiciary directly. Still, in the background, Congress can threaten to deprive the judici-

49 See Cass R. Sunstein \& Edna Ullmann-Margalit, Second-Order Decisions, 110 ETHICS 5, 7 (1999) (defining second-order decisions as "decisions about the appropriate strategy for reducing the problems associated with making a first-order decision").

${ }^{50}$ Ex parte Merryman, 17 F. Cas. 144, 148 (C.C.D. Md. 1861) (No. 9487) (declaring that Lincoln, in suspending habeas corpus, "exercised a power which he does not possess under the constitution"). 
ary of funds and strip it of jurisdiction, and this threat could lead to an impasse if the judiciary attempted to defy it.

The academic literature on constitutional conflicts involving the judiciary has focused on the "passive virtues," in Alexander Bickel's phrase. ${ }^{51}$ Bickel believed that the judiciary should exercise the passive virtues when the constitutional stakes are high, meaning that the judiciary should dodge the issues by invoking doctrines of abstention and procedural doctrines such as standing. Similarly, Cass Sunstein has argued that judges should try to decide cases on narrow and shallow grounds where possible. ${ }^{52}$ If a dispute between the executive and Congress requires either a decision about the meaning of a statute or a decision about the branches' relative constitutional authority, the judiciary should, if possible, decide on the former ground, so that the constitutional question is put off; even if forced to decide the constitutional question, judges should say no more than necessary to resolve the case at hand and should not engage in unnecessarily ambitious theorizing.

It is clear that these scholars advocate the middle way of ambiguous acquiescence in these cases: acquiescence, because the court does not dispute the constitutional claims of the other branches; ambiguous, because the court does not adopt their claims either. Rather, the largest claims are left open for the future. Constitutional precedents on the merits of those claims are either nonexistent (under the passive virtues approach) or narrow and shallow (under Sunstein's minimalist approach).

As we have seen, however, ambiguous acquiescence is not always possible and, even when possible, not always optimal. ${ }^{53}$ Ambiguous ac-

51 BICKEL, supra note 5, at 111.

${ }^{52}$ See generally CASS R. SUNSTEIN, ONE CASE AT A TIME: JUDICIAL MINIMALISM ON THE SUPREME COURT (1999).

${ }^{53}$ To be clear, neither Sunstein nor Bickel argues that courts should always refrain from taking strong positions. Sunstein's decision-cost/error-cost framework makes clear that the choice between minimalism (here, ambiguous acquiescence) and maximalism (here, a clarifying showdown) depends on the short-term costs and long-term benefits of each. Id. at 46-50. We attempt to clarify the social costs and benefits and examine whether institutions will supply the socially optimal rate of showdowns. We also note that many of the virtues of minimalism that Sunstein identifies are confined to judicial minimalism, and do not apply to ambiguous acquiescence as between the other branches. To take just one example, Sunstein believes that judicial minimalism can, in some circumstances, promote democracy by leaving most policy judgments to elected officials; as between the President and legislators, all of whom are elected, democratic values do not, in a general sense, favor either acquiescence or mutual assertion. Along this dimension, the case for judicial minimalism is much stronger than the 
quiescence is possible only when the agent's alternative explanation for its acquiescence is credible. In the case of the judiciary, consider the use of the standing doctrine to avoid resolving conflicts between Congress and the executive. If the judiciary repeatedly uses the standing doctrine in this way, and manipulates it so as to avoid resolving cases even when the standing doctrine would ordinarily not present a barrier, then observers will infer that the judiciary simply is unwilling to assert constitutional authority over the dispute at hand. Over time, acquiescence will become less ambiguous and, eventually, unambiguous. This is, in fact, what has happened for a wide array of interbranch conflicts.

For example, the judiciary has refused to hear on the merits cases in which members of Congress have sought to prevent the President from sending troops abroad without complying with the War Powers Resolution. The courts have not held that the War Powers Resolution is unconstitutional; instead, they have avoided the merits by invoking doctrines of justiciability. ${ }^{54}$ So while the constitutionality of the War Powers Resolution remains unresolved, the practical effect of the judiciary's decisions is to allow the President to ignore it. The judiciary's acquiescence was at one time ambiguous because the early cases left open the possibility that the resolution would be struck down once someone had standing. As additional cases have been brought, and the judiciary has continued to find reasons to avoid deciding the merits, this ambiguity has nearly disappeared.

Even when ambiguous acquiescence is credible, it is not always optimal. As we saw, ambiguous acquiescence is an optimal strategy only in certain circumstances: namely, when the cost of present delay and the benefit of future clarity are moderate. Consider, as an example, a case in which the judiciary believes that executive actions during a war violate constitutional rights of citizens but fears that if it tries to stop the executive, the executive will defy it, provoking a constitutional crisis. Still, such an impasse will be desirable if it is predictable that in the present the cost of delay is not too high, and in the future the issue is likely to recur. This might be more plausible today, where some

argument in favor of the political branches avoiding showdowns with each other. But cf. Cass R. Sunstein, Nondelegation Canons, 67 U. CHI. L. REV. 315, 317 (2000) (suggesting that Congress has superior democratic credentials to the executive such that courts concerned to promote democracy should require express congressional resolution of major issues, especially those touching on constitutional rights).

${ }^{34}$ See the various opinions in Campbell $v$. Clinton, 203 F.3d 19, 20-22, 24, 28 (D.C. Cir. 2000), denying legislators standing to seek judicial remedy where political options were available, albeit unsuccessful, and in concurring opinions arguing that the claims are not justiciable and moot. 
fear that the war on terror will extend indefinitely into the future, than during the Civil War, when the war seemed like an interruption of normal politics. ${ }^{55}$ So it may not be surprising that courts are more willing to challenge the executive branch today than in the past. We should interpret this unprecedented level of judicial activity as reflecting an attempt to plumb public constitutional sentiment, even at some risk to the short-term functioning of the government, since a clearer sense of public sentiment might be necessary in order to support a long-term constriction of civil liberties.

\section{E. A Note on Aggrandizement}

Some people argue that uncertainty about the constitutional allocation of powers deters aggrandizement, making institutions cautious about pressing the limits of their power. They further argue that showdowns should be discouraged because the clarification of powers that occurs after a showdown will have negative rather than positive consequences. Namely, with the uncertainty eliminated, institutions will press the limits of their power, and the public will suffer as a result. ${ }^{56}$

The argument is hard to criticize because so many of its elements are poorly articulated. ${ }^{57}$ An institution that presses the limits of its

${ }^{55}$ We do not actually think this common claim makes sense; it rests on a confusion between foresight and hindsight. See ERIC A. POSNER \& ADRIAN VERMEULE, TERROR IN THE BALANCE: SECURITY, LIBERTY, AND THE COURTS 255 (2007) (recalling theories that World War II might not have a conventional ending, and drawing analogies to the "national struggle[s] to defeat polio, or the Mafia, or the Ku Klux Klan," in which victory occurred despite the inability to define victory or date it precisely).

${ }^{56}$ We have not found a detailed defense of this view; however, it is clearly a part of legal-academic folkways. For brief gestures in this direction, see JOHN YOO, THE POW. ERS OF WAR AND PEACE: THE CONSTITUTION AND FOREIGN AFFAIRS AFTER 9/11, at 11 12 (2005) ("In the area of foreign affairs, the Constitution does not establish a strict, legalized process for decision making. Instead, it establishes a flexible system permitting a variety of procedures. This not only gives the nation more flexibility in reaching foreign affairs decisions, it gives each of the three branches of government the ability to check the initiatives of the others in foreign affairs." (emphasis added)); Bruce Ackerman, The Emergency Constitution, 113 YALE L.J. 1029, 1042 (2004) ("During normal times, the common law fog allows judges and other legal sages to regale themselves with remarkably astringent commentaries on the use of emergency powers, cautioning all and sundry that they are unconstitutional except under the most extreme circumstances. This creates $a$ cloud of suspicion and restrains officials who might otherwise resort to emergency powers too lightly." (emphasis added)).

${ }^{37}$ For example, the argument seems to assume that the institutions are risk averse. Risk-neutral institutions would not treat an ambiguous rule as anything but a point along a probability distribution, and would discount the benefits and costs of various courses of action accordingly. However, when we relax the assumption of personified branches in Part III, we will see that it is problematic to ascribe risk aversion to an insti- 
power might do well or poorly for the public, and whether it does depends on various factors. We might think that the judiciary ought to press the limits of its power in order to protect civil liberties against a despotic government, but not to substitute its policy judgment for that of Congress. We might think that the executive should press the limits of its power to counter an existential threat or a Great Depression, but not to engage in ordinary law enforcement activities. Since institutions share power, whether one institution should press the limits of its power depends to a great extent on whether other institutions are misusing their powers. It is hard to see how ambiguity about the contours of authority could be desirable in the abstract; its effect is just to create uncertainty among citizens who are regulated by the various institutions. All else equal, uncertainty is a systemic cost, which can only be justified on second-best grounds; what those grounds might be is obscure.

Indeed, political scientists commonly argue that clear allocations of authority are essential to constitutional stability. Barry Weingast, for example, argues that in stable constitutional systems governments refrain from crossing constitutional boundaries because they fear that multiple groups will oppose them if they do so. In Weingast's model, a single group does not have the power to prevent government excesses, but if groups coordinate, then they can, in tandem, resist the government. ${ }^{58}$ In the absence of rules that describe the limits of government action, the groups lack a focal point that can provide the basis for coordination, and the government can suppress them through a divide and conquer strategy. ${ }^{59}$ Governmental violation of a clear allocation of power can trigger general resistance because the stipulated allocation serves as a focal point for resistance. ${ }^{60}$ Creeping aggrandizement is more, not less, likely when the constitutional allocation of powers is ill defined.

tution such as the presidency, Congress, or the judiciary. The President might well believe that risk taking is the best chance for obtaining electoral returns, and members of Congress might have similar views. Politicians are disciplined by parties, and party leaders might believe that party members best help the party by taking risks and might thus be willing to subsidize those who take risks and fail.

${ }^{58}$ See Barry R. Weingast, Self-Enforcing Constitutions 3 (Nov. 2005) (unpublished manuscript), available at http://polisci.stanford.edu/faculty/documents/weingast-selfenforcing\%20constitutions.pdf; see also James D. Fearon, Self-Enforcing Democracy 13 (Aug. 24, 2006) (unpublished manuscript), available at http://www.stanford.edu/ -jfeason/papers/sedapsa06.pdf (applying Weingast's model to elections).

${ }^{59}$ Weingast, supra note 58 , at $3-4$.

60 Id. at 22. 
In sum, the argument that ambiguous constitutional norms deter governments or parts of government from engaging in selfaggrandizing behavior is implausible. The argument lacks an account of the interests and capacities of the relevant agents, and so is hardly more than a surmise. At the same time, there are several independent reasons for thinking that institutional self-aggrandizement is deterred by clear rather than ambiguous rules.

\section{THE SUPPLY OF CONSTITUTIONAL SHOWDOWNS}

Given the social costs and benefits of showdowns, we have argued, there is some socially optimal rate, timing, and scale of showdowns. It is hard to say anything precise about these factors in the abstract, but we have sketched the critical variables and the conditions under which social welfare is increased or decreased by showdowns. In this Part we turn from the demand side to the supply side, from the social calculus to the private calculus of institutions. We use "private" not in its colloquial sense, but as shorthand for the decentralized decisions of branches in a separation of powers system as opposed to the decisions of a benevolent social planner.

Even without a precise account of the socially optimal rate, timing, and scale of constitutional showdowns, we can say something about the supply side. We will argue that there is no general reason to think that the interaction of lawmaking institutions produces socially optimal showdowns. Section A suggests that the private calculus predictably diverges from the social calculus. Section B denies that there is any invisible-hand mechanism that causes the decentralized decisions of institutions to approximate the social optimum. Section $\mathrm{C}$ relaxes the assumption that each branch is a unitary actor, but argues that relaxing the assumption generally has no effect on our conclusions, and in some cases may even strengthen them. We also consider the role of political parties, with the same conclusion. Section D provides illustrations of the divergence between private and social costs.

\section{A. The Private Calculus}

Showdowns occur when one branch confronts another over a constitutional issue. But when will such confrontations occur? As we discussed in Part I, showdowns occur when public constitutional sentiment regarding the location of authority over some policy area is uncertain, and each side believes that if it asserts its own authority, the other side will blink. 
Game theory aficionados will draw the analogy to the Chicken Game, in which each player receives the highest payoff if it confronts while the other player avoids, but in which mutual confrontation produces the worst outcome for both players. For a nonconstitutional example, the government shutdowns of 1994 and 1995 resembled a Chicken Game in which neither Clinton nor Gingrich blinked until it was too late; for a constitutional example, the McCardle episode resembled a game in which the Republican Congress drove straight while the Court swerved. Our version is a little more complicated, involving both asymmetric information and a continuum of choices, for which we draw on standard bargaining theory. ${ }^{61}$ For our purposes, precisely which model best describes a given interaction or context is not the main question; rather, we focus on the payoffs to individual players.

Institutions will decide whether to engage in showdowns by comparing the benefits and costs to themselves of doing so-specifically, the "private" costs and benefits. What are the costs and benefits to institutions of engaging in showdowns? Here again, we assume that institutions can be treated as having a composite utility function-a standard personifying assumption justified by the fact that every institution has internal rules for aggregating individual preferences into institutional preferences, and an assumption that simplifies the presentation. In Part III.C, we relax this assumption and examine cases in which the interests of the individuals who staff institutions, and of political parties, diverge from the interests of the institutions themselves.

Both the benefits and the costs depend on what institutions maximize. Plausible maximands include power in various senses-including the scope of the institution's legal authority, the ability to carry out a preferred course of action, and the ability to force other institutions to comply with a preferred course of action; popularity, or diffuse support among the general public; and ideological satisfaction with policy. Dif-

${ }^{61}$ See supra note 40 and accompanying text. Other interactions resemble a Prisoner's Dilemma, in which each player receives the highest payoff if it defects while the other cooperates, and the lowest payoff if it cooperates, while the other defects; the dominant strategy for both is to defect, and in a single-shot interaction both do so, even though both would be better off if they could cooperate. On the other hand, cooperation can be sustained in a repeat-play Prisoner's Dilemma, although it is only one possible equilibrium. Still other interactions resemble a Battle of the Sexes, in which both players prefer to coordinate on a common venture, yet each prefers that both coordinate on a different common venture. These models of interaction are all at least partially conflictual, although they mix cooperation and conflict. In the background are many interactions in which branches have joint interests in cooperation without significant distributive conflicts. However, pure coordination interactions are not as theoretically interesting as (partially) conflictual interactions, so we will focus on the latter. 
ferent institutions pursue different aims, with different weightings, at different times. Benefits thus arise when a showdown expands an institution's power (somehow defined), increases its popularity or public standing, or enables it to satisfy programmatic and policy goals. Costs are the flip side of benefits: a showdown might diminish institutional power, erode popularity, or frustrate policy aims.

Of course, there are severe conceptual and empirical difficulties in specifying these costs and benefits more concretely. ${ }^{62}$ Happily, for our purposes we need not offer a precise specification of all private costs and benefits to institutions. Even without such a specification, we can ask whether institutional decisions take into account all social costs and benefits. The answer is no, even or especially if the players manage to cooperate in a repeated Prisoner's Dilemma, or to avoid disastrous crashes in a Chicken Game, and so on. In general, the decision by any particular branch to confront another branch over a constitutional question, or to avoid another's confrontation, will not take into account all the social costs and benefits of showdowns. Consider the following externalities-costs to third parties, including future generations, that the players will systematically tend to ignore.

\section{Governance Costs}

Actors incur at least some of the costs of the showdown. If Congress and the President seek to resolve the war in America's interests, and disagree only on whether termination should be sooner or later, then a showdown might indeed interfere with their overlapping goals. If the two agents are arguing about lines of authority, they are not arguing abouit the war, which means that they lose a valuable opportunity to generate information and reach a mutually acceptable war strategy.

Suppose that Congress and the President agree that the war should end in four months, but the President thinks that a token force of 10,000 should stay behind and Congress believes that only 2000 should stay behind. Suppose further that a showdown delays the eventual compromise of 6000 so that the original force remains for six rather than four months. Both sides are hurt by the showdown because both preferred the early disengagement. The cost could be ideological or electoral or both.

${ }^{62}$ See generally Levinson, supra note 22 (discussing the aims of institutions and the personnel who occupy them). 
The problem is that neither side fully internalizes the costs. If the war goes on too long because the agents are arguing, the public might be in no position to sanction the agents. If it punishes the Republican President at the polls, it benefits the Democratic Congress; if it punishes the Democratic Congress, it benefits the Republican President. Agents will have excessive incentives to engage in showdowns, all else equal.

On the other hand, electoral incentives might operate in a different fashion. Suppose that agents believe that the public will punish incumbents if governance is interrupted, and vote in favor of challengers. To avoid this threat to their offices, elected officials might implicitly agree to avoid showdowns even when they are, in the long term, socially beneficial. In our example, the two-month delay might be a cost-justified way to clarify who decides how to terminate a war. But the agents avoid the delay because the actual governance costs are exaggerated in their private calculus.

\section{Certainty}

Actors avoid confrontation when it is privately beneficial to do so, even if conflict would create precedents that would benefit future generations, all else equal, by clarifying the rules of the game. More conflict now can mean lower transaction costs for several future generations; even with discounting, the latter benefit can exceed the former cost. In the recent controversy over the firing of U.S. Attorneys, for example, commentators parsed the complex issues of executive privilege with reference to one major Supreme Court case that is over thirty years old $^{63}$ and a few successor cases from the D.C. Circuit. ${ }^{64}$ There is also some guidance from nonjudicial precedents; consider the argument that Secretary of State Condoleezza Rice has no constitutional basis for refusing to testify before Congress about the decision to invade Iraq, because Cabinet officials from previous administrations testified in similar circumstances. ${ }^{65}$ Still, such precedents are slightly muddled by the fact that the executive and legislators often strike a bargain whereby executive officials will testify, but will proclaim that

${ }^{63}$ United States v. Nixon, 418 U.S. 683 (1974).

${ }^{6}$ See, e.g., Senate Select Comm. on Presidential Campaign Activities v. Nixon, 498 F.2d 725 (D.C. Cir. 1974). For an overview of executive privilege, explaining the many severe uncertainties in this area of law, see Posting of Cass R. Sunstein to the University of Chicago Law School Faculty Blog, Executive Privilege: A Primer, http://uchicagolaw.typepad.com/faculty/2007/03/executive_privi.html\#more (Mar. $26,2007,11: 38 \mathrm{CST}$ ) (summarizing executive privilege in eight points).

${ }_{65}$ Frank Rich, Is Condi Hiding the Smoking Gun?, N.Y. TIMES, May 6, 2007, § 4, at 15. 
they are doing so "voluntarily," rather than because Congress has constitutional power to force them to do so. More seriously, in many cases early bargains will head off a nascent conflict, resulting in no precedent at all.

In general, current actors may have no incentive to take into account clarification benefits for third parties, especially for future generations. This means that future actors will incur transaction costs coping with longstanding uncertainties that could have been decisively clarified, one way or another, in a past constitutional showdown-a showdown that never occurred because it was not in the interests of the then-dominant actors to engage in clarifying conflict. ${ }^{66}$

\section{Option Value and Unnecessary Precedents}

On the other hand, future generations will often benefit from a better precedent made later, with more information, rather than a precedent made today, with less information. Delay would then be desirable, from the social point of view, if more information can be collected in the interim. A current showdown, even if it benefits current actors, might create a premature precedent, freezing the constitutional rules before the relevant considerations are well understood.

Collecting more information is especially likely to be useful in a static environment, but delay is often desirable in a changing environment as well, albeit for other reasons. A current issue that provokes severe conflict may simply disappear from the scene due to economic, technological, or political change. Where this is so, social resources spent on an authoritative resolution of the issue will be a partial or total waste from the standpoint of future generations.

Where a showdown sets a precedent that would have been better set later, with more information, or that need never have been set at all, because the relevant issue soon disappears altogether, we will speak of an unnecessary precedent. Let us define the precedential effect of a showdown as having two components: $D$, the direct precedential benefit (the decision settles, for example, whether paper

${ }^{66}$ This adapts a point made by Owen Fiss about settlement in litigation: the private calculus of settlement fails to take into account the benefits to third parties of creating precedents. See Owen M. Fiss, Comment, Against Settlement, 93 YALE L.J. 1073, 1085 (1984). It is also a staple of the law and economics literature, though economists tend to be less critical of settlement. See, e.g., Landes \& Posner, supra note 4, at 261 (demonstrating that precedents can act as private, as well as public, goods); Shavell, supra note 4, at 112-13 (concluding that settlement is always socially preferable to trial but recognizing the social value of setting precedents). 
money is constitutional) and $I$, the indirect precedential benefit (the decision establishes whether "due process" includes substantive fundamental rights ${ }^{67}$ ). There is a cost $C$ of generating the precedent, which includes both the direct costs of decision making and political conflict involved in generating the precedent, and also the cost that arises from deciding the precedent now rather than later, with more information.

An unnecessary precedent, then, is simply one where $C>D+I$. If the value of waiting for more information is high, or if the showdown that gives rise to the precedent involves costly political conflict, then $C$ will be high, and it will be better not to create a precedent now or at all. If the precedent directly governs an issue that will soon disappear and thus lacks significance to future generations, then $D$ is low; unless $I$ is especially high, the precedent is likely to be unnecessary.

This is the social calculus, but the private calculus diverges. Current actors will not take into account these benefits of delaying the formation of precedents, and of pretermitting conflict over ephemeral issues. Just as current actors will avoid constitutional showdowns altogether even if the clarification benefits would exceed the private costs, by the same token they will engage in constitutional showdowns now, rather than later or not at all, if it is to their advantage to do so. These points emphasize that, from a social point of view that aggregates (with appropriate discounting) the interests of current and future generations, one must consider not only the number of showdowns, but their distribution over time, relative to changes in political and social problems.

\section{Aggrandizement and the Checking Function}

Suppose we have a theory stating that a separation of powers of strength $S$ is optimal, where $S$ specifies the ratio of the power of each branch of the national government to the total power of the national government. $^{68}$ (If one branch has taken over the whole government,

${ }^{67}$ Griswold v. Connecticut, 381 U.S. 479 (1965). Note that the direct precedential benefit of Griswold was low, because only a few other states banned the sale of contraceptives, but its indirect precedential benefit was high. See Roe v. Wade, 410 U.S. 113, 152-53 (1973) (relying on Griswold to conclude that the "right of privacy . . is broad enough to encompass a woman's decision whether or not to terminate her pregnancy").

${ }_{68}$ This theory might be legal, based on an account of the constitutional distribution of power, or it might instead be rooted in democratic theory or political morality. For our purposes the source of the theory is irrelevant. 
$S=1$ for the victorious branch and $S=0$ for the others; if each of the three branches is of equal strength, $S=0.33$ for each. An $S$-function might, for example, specify that the distribution of power should be $\{$ President $=0.5$, Congress $=0.25$, and Supreme Court $=0.25\}$. Obviously these are schematic, but are sufficient to illustrate our simple point.) Suppose also that one institution-say, the presidency-is increasing its strength such that its strength exceeds what is specified in the social $S$-function. Then current citizens and future generations will benefit from showdowns that check the expanding power of that branch.

However, current institutions will be too passive-they will challenge the expanding institutions too rarely, and with too little intensity-because they will not capture the benefits to future generations of exercising the checking function. The largest harms from an unbalanced government will be likely to materialize in the medium- and long-term future, beyond the time horizon of current institutions. Suppose, for discussion's sake, that one thinks the current power of the Supreme Court is excessive-that the Court's $S$-factor is too high. Then one might regret the many occasions in the past two generations on which Congress and the President have foregone opportunities to challenge the Court's power-including the many cases in which the Court employed creative or disingenuous statutory interpretation to protect its own jurisdiction, and the nonjudicial branches then refused to force a constitutional showdown by clarifying the underlying statutes.

The point that current checking will fail to internalize the interests of future generations would hold even if there were only two branches in the picture. With three branches, however, externalities among current actors are also possible. One possibility is that the strongest branch-the one with the highest $S$-value-can play a divideand-conquer game, alternating alliances with the weaker branches until it effectively dominates both. Here, the externality is that each of the weaker branches fails to take into account the full costs of its short-run opportunism to the other weak branch and to the balance of the whole system. Conversely, the weaker branches will be tempted to free-ride on each other's investment in checking the strongest branch, so long as there is a positive cost to a showdown that checks aggrandizement. A configuration President $=0.5$, Congress $=0.5$, Supreme Court $=0$ f might yield far more aggressive checking of presidential expansion than would a configuration such as (President $=0.5$, Congress $=0.25$, Supreme Court $=0.25\}$. In the latter scenario 
Congress and the Court will face temptations to mutual free-riding, while in the former scenario the concentration of nonpresidential power in a single place reduces the scope for presidential aggrandizement. $^{69}$

Obviously, many other scenarios are possible. We have assumed, for example, that showdowns will help to check aggrandizement, but this is not obviously true. Showdowns might actually provide the very opportunity the stronger branch has been seeking to crush its adversaries or to clarify their impotence, creating a highly visible precedent that will underscore its power. We mention these scenarios just to illustrate the types of externalities, even with the current generation, that can cause insufficient investments even in showdowns that would check aggrandizement if they occurred. The divergence between private and social costs and benefits will cause suboptimal checking, and there is no reason to think the failure of institutions to invest in showdowns that would promote optimal checking is somehow offset by their private-regarding incentive to invest in showdowns that will promote their own power. There is no invisible-hand mechanism that causes one type of failure to offset the other-a point to which we return below.

\section{A Note on Representation-of the Present and the Future}

Particular political mechanisms may cause some of these externalities to be internalized. Thus the interests of current citizens and litigants will be partly taken into account by the more-or-less representative national institutions and the presidency and Congress, although a large body of literature in public choice and political economy details agency slack and other failures of representation that affect these institutions. The courts are less directly representative; although they tend to follow the national election returns eventually, they do so only with a time lag, and are used by outgoing political parties to entrench their preferences against the incoming political tide. ${ }^{70}$

${ }^{69}$ Potentially offsetting the free-rider problem is the multiplicity of checking agents, which may raise the likelihood that at least one of them will step forward to challenge an expansion of power. However, as we discuss shortly, there is no general mechanism ensuring that one effect precisely compensates for the other.

${ }^{70}$ See Jack M. Balkin \& Sanford Levinson, Understanding the Constitutional Revolution, 87 VA. L. REV. 1045, 1066-83 (2001) (observing that partisan entrenchment is the "temporal extension of partisan representation"); Howard Gillman, How Political Parties Can Use the Courts To Advance Their Agendas: Federal Courts in the United States, 18751891, 96 AM. POL. SCI. REv. 511, 515-21 (2002) (concluding that the increased power 
However, current politics will not generally internalize the interests of future generations as such. Current voters will themselves care about future generations, and this altruistic interest will then be reflected in the policies of current lawmakers (putting aside agency slack between current lawmakers and current voters). This intergenerational altruism, although real, is plausibly seen as a weak force, analogous to international altruism through foreign aid, on which developed democracies spend a tiny fraction of their resources. The future is another country, ${ }^{7}$ which means that current voters and their agents in national lawmaking institutions will tend to subordinate the interests of the future, just as they do the interests of other nations.

In principle, agency slack between current voters and current representatives might actually offset the weakness of current voters' altruism toward future generations. Current representatives who enjoy loose political constraints might take it into their heads to crusade on behalf of future generations. Or, more familiarly, they might use their political freedom to enrich themselves, pursue current-regarding rather than future-regarding ideological enterprises, and so on. In general, there is no reason to think that any configuration of current politics, whether low-slack or high-slack, will systematically internalize future generations' interests, although it may look to the future in episodic and unpredictable ways.

Our conclusion is not that the private calculus of the costs and benefits of engaging in a showdown never tracks the social calculus, aggregating the interests of succeeding generations over time. In particular cases, institutions may happen to engage in showdowns when that would be desirable from a social perspective, or to avoid confrontation when that too would be socially desirable. The claim is that there is no general mechanism aligning private institutional incentives with the social optimum. Where institutional decisions happen to track the optimum, it is a lucky coincidence; over a large set of cases, wide divergences will predictably occur, and the divergences will be strongly biased in favor of the interests of current generations.

and jurisdiction of federal courts from 1875 to 1891 was a result of Republican efforts to entrench economic nationalism).

${ }^{71}$ Eric A. Posner, Agencies Should Ignore Distant-Future Generations, 74 U. CHI. L. REV. 139,142 (2007) (asserting that agencies treat future generations as they do the wellbeing of foreigners, about whom voters care little). 


\section{B. An Invisible Hand?}

So far, we have suggested that there is no general reason to think that the decentralized decisions of lawmaking branches and institutions will result in socially optimal showdowns. It might be suggested that decentralized decisions might result in socially optimal showdowns by some sort of invisible-hand mechanism. Even if each institution considers only its private costs and benefits, rather than the social costs and benefits, perhaps a kind of analogy to markets operates, such that the social optimum arises as "the result of human action, but not the execution of any human design." gestions, consider the claims that the "fog" of legal uncertainty in constitutional law has the systemically beneficial effect of deterring aggrandizement, ${ }^{73}$ or the suggestion that " $[t]$ he governmental order that arises in our system of separation of powers paradoxically has much in common with the more spontaneous order that may arise where individuals work out mutually advantageous arrangements without the aid of a central coordinator." ${ }^{74}$ The basic form of the argument is that emergent constitutional norms, customs, conventions, and precedents are or may be systemically optimal, even if no actor aims to promote an optimal system.

Of course this is possible, but there is no reason to think that it actually is so. In general, these are methodologically suspect functional explanations; ${ }^{75}$ they speculate that private decisions produce social benefits without specifying how exactly this occurs. For a genuine invisible-hand process to operate, there must be some mechanism that explains the connection between individual-level behavior and the systemic optimum. ${ }^{76}$ Absent intentional optimizing by a social planner, the social optimum will be produced only by some sort of evolutionary or feedback mechanism.

72

ADAM FERGUSON, AN ESSAY ON THE HISTORY OF CIVIL SOCIETY 119 (Fania OzSalzberger ed., Cambridge Univ. Press 1995) (1767).

${ }^{73}$ Ackerman, supra note 56, at 1042.

${ }^{74}$ McGinnis, supra note 9, at 303.

${ }^{75}$ See JON ELSTER, EXPLAINING SOCIAL BEHAVIOR: MORE NUTS AND BOLTS FOR THE SOCIAL SCIENCES 5 (2007) (identifying functional explanations as those that explain behavioral patterns by describing their consequences and not their causes).

${ }^{76}$ See Edna Ullmann-Margalit, Invisible-Hand Explanations, 39 SYNTHESE 263, 267 (1978) (arguing that the success of an invisible-hand explanation depends on the nature of the mechanism that "aggregates the dispersed individual actions into the patterned outcome"). 
In ideal markets, there is just such a mechanism: the price system, enforced by competition. Economic actors who are not aiming to produce public benefits will do so by rationally pursuing their selfinterested ends; doing so embeds information about supply and demand in prices and propagates that information through the economic system. ${ }^{77}$ Under the idealized conditions of textbook welfare economics, the price system ensures that all Pareto-improving trades are consummated. However, nothing in the separation of powers system corresponds in any robust way to the role of the price system (in ideal markets). ${ }^{78}$ There is no general mechanism ensuring that the decentralized decisions of branches will produce the optimal level of uncertainty, except possibly in an accidental and temporary fashion. As in the ideal market and some real markets, the separation of powers system has no central director, but it does not follow that the separation of powers system displays "spontaneous order" or that it will produce "mutually advantageous arrangements." Furthermore, even if all such arrangements are made, there is no guarantee that the resulting distribution of political power will be socially optimal, because there are enduring divergences between private and social costs and benefits.

Likewise, there is no reason to expect that interaction between national lawmaking institutions will tend to produce anything like efficient customs or norms. In general, the most plausible case for the emergence of efficient custom involves conditions of symmetry and reciprocity, in which agents know that they will be on both sides of similar transactions over time and thus have an incentive to follow the rule that maximizes aggregate welfare for all concerned. The interaction of lawmaking institutions is not like this; a custom that recognizes broad executive privilege, for example, systematically favors the presidency in all future interactions, and will thus predictably be supported by Presidents and opposed by legislators, whatever its aggregate welfare effects.

${ }^{77}$ F.A. Hayek, The Use of Knowledge in Society, 35 AM. ECON. REv. 519, 526-27 (1945) (arguing that the price system ought to be seen as a "mechanism for communicating information").

${ }^{78}$ Gary Becker suggests that interest-group pressures on legislatures produce efficient legislation. See Gary S. Becker, A Theory of Competition Among Pressure Groups for Political Influence, 98 Q.J. ECON. 371 (1983). But even if this is true, taken in isolation, there is no guarantee that the outputs of the whole lawmaking system will be efficient; that further thesis requires that the interaction between the legislature and the nonlegislative branches conduce to efficiency. 


\section{Branches, Individuals, and Parties}

In order to clarify our main theses, we have indulged the deliberately artificial assumption that branches of the national government are personified rational actors. Although this is a standard assumption in constitutional theory, it is of course false. ${ }^{79}$ The interests of individuals who fill the branches will often, perhaps systematically, diverge from the institutional interests of those branches. Moreover, individual officials are members of parties whose interests cut across those of institutions. Does the lack of realism undermine our conclusions?

Relaxing the assumption of personification should generally strengthen our conclusions, because introducing a divergence between individual and institutional interests, or party interests and institutional interests, makes it even more unlikely that institutions will act so as to produce the socially optimal level and distribution of constitutional showdowns. At worst these complications will be random with respect to our conclusions, sometimes strengthening and sometimes weakening them.

\section{Branches and Individuals}

Consider, as an example, the problem of underinvestment in showdowns that would check aggrandizement (here again defining aggrandizement as any change that gives one institution more power than specified in an ideal $S$-function). We saw two mechanisms that might cause, for example, a current Congress to underinvest in showdowns that would check the expanding powers of the presidency. The first is that the current Congress would not fully internalize the interest of future generations in enjoying an optimal separation of powers system; the second is that Congress might attempt to free-ride on the checking function of the Supreme Court (which might in turn be trying to free-ride on the checking function of Congress).

The divergence between the interests of individual legislators and the institutional interests of Congress provides a third mechanism, quite possibly cumulative of the first two. David Hume argued, in effect, that lack of coordination among members of Parliament enabled

${ }^{79}$ See Levinson, supra note 22, at 926-30 (arguing that government officials do not operate to aggrandize the institutions in which they work because they pursue the interests of their constituents or themselves). 
the Crown to buy a decisive bloc of legislative support on the cheap. ${ }^{80}$ Modern commentators have extended the point, showing that because Congress is a "they," not an "it," and because it is a "they" with many members, legislators face severe problems of collective action in organizing to oppose the executive, even where it would be socially optimal to do so. ${ }^{81}$ The internal multiplicity of Congress increases the probability that Congress as a whole will underinvest in checking the executive.

Of course, the same collective action problems that hamper Congress in opposing the executive might also prevent Congress from aggrandizing power at the expense of the executive or the courts, and that result might itself be socially desirable. Consider that internal legislative disagreement, preventing formation of a sufficiently large coalition, saved Andrew Johnson from being impeached. It has been claimed, plausibly enough, that a successful impeachment of Johnson would have decisively tilted the American separation of powers system in the direction of a quasi-parliamentary form of government. ${ }^{82}$

But there is no reason to think that this second possibility somehow balances out the first. There is no big ledger where the beneficial effects of internal legislative conflict balance out the detrimental effects, and no price-like mechanism makes the former equal to the latter in any event. The effects of Congress's collective action problems are, at best, a random variable with respect to the socially optimal level and distribution of constitutional showdowns. Once the divergence between individual and institutional interests is taken into account, there is even less reason to think that decentralized institutional interaction will have any systematic or predictable tendency to supply showdowns in a socially desirable manner.

\section{Branches and Parties}

Political parties have been robust forces in the American constitutional system since the early nineteenth century, and their interests are often at variance with the interests of institutions. Either by virtues of selection, incentives, or both, legislators, executive officials,

${ }^{80}$ See Adrian Vermeule, Hume's Second-Best Constitutionalism, 70 U. CHI. L. REv. 421, 428-29 (2003).

${ }^{81}$ See Kenneth A. Shepsle, Congress Is a "They," Not an "It": Legislative Intent as Oxymoron, 12 INT'L REV. L. \& ECON. 239 (1992).

${ }^{82}$ Jon Elster, supra note 28, at 34-35 (citing ARTHUR M. SCHLESINGER, JR., THE IMPERIAL PRESIDENCY 74-75 (1973), and DANIEl LAZARE, THE Frozen RePubliC: HOW THE CONSTITUTION IS PARALYZING DEMOCRACY (1996)). 
and judges identify with partisan positions. The consequence is that the separation of powers system functions differently in times of unified or divided government: under unified government, parties may effectively reallocate constitutional authority among the branches of government; under divided government, parties will cause interinstitutional conflict and may provoke showdowns, but only to the extent that partisan interests warrant. ${ }^{83}$

However, it goes too far to claim that the American constitutional system displays "separation of parties, not powers"; ${ }^{84}$ rather, it displays both separation of powers and parties in a complicated interaction. Sometimes partisan interests come to the fore and trump the institutional interests of branches. ${ }^{85}$ On the other hand, sometimes partisan interests are themselves secondary. In one standard case, parties are internally fractured. The post-9/11 legislation proposed by the Bush administration faced opposition from both civil-libertarian Republicans and civil-libertarian Democrats; the resulting coalition had enough clout to narrow the grant of new powers to the executive in the USA PATRIOT Act. ${ }^{86}$ In that statute, sunset provisions were included at the behest of the Republican leadership of the House, over the administration's opposition.

In those cases the issue-the point at which the security-liberty tradeoff should be struck-was single dimensional, but legislators did not line up neatly by party along the single dimension. In other cases, parties are fractured because issues are multidimensional. Famously, the enactment of civil rights statutes in the later 1950s and early 1960s, culminating in the Civil Rights Act of 1964, was greatly complicated by the fact that geography and other affiliations cut across partisan affiliation; southern Democrats who used the filibuster to strangle early civil rights proposals were eventually defeated by a coalition of northerners and westerners from both political parties.

Finally, in yet other cases, parties are internally cohesive and take opposing positions, but crucial individuals place institutional interests

${ }^{83}$ Daryl J. Levinson \& Richard H. Pildes, Separation of Parties, Not Powers, 119 HARV. L. REV. 2311, 2338-47 (2006).

${ }^{84}$ See id.

${ }^{85}$ For cases demonstrating this, see id.

${ }^{86}$ See 1 BERNARD D. REAMS, JR. \& CHRISTOPHER T. ANGLIM, USA PATRIOT ACT: A LEGISLATIVE HISTORY OF THE UNITING AND STRENGTHENING OF AMERICA BY PROVIDING APPROPRIATE TOOLS REQUIRED TO INTERCEPT AND OBSTRUCT TERRORISM ACT, PUBLIC LAW NO. 107-56 (2001), at xlvi-xlvii (2002) (describing a coalition of civil libertarians of both parties that objected to some of the administration's initial proposals, which were never adopted). 
above partisan ones. Arlen Specter, John Warner, and Lindsey Graham, powerful Senate Republicans, have opposed the Bush administration on a range of national security issues since $9 / 11$, in part in order to protect the Senate's prerogatives against perceived executive aggrandizement. During the fight over Roosevelt's court-packing plan, crucial Democratic members of Congress defected to the opposition, in part because of concerns about executive tyranny-a concern that was fueled by the very size of Roosevelt's partisan majority in Congress. ${ }^{87}$

The mechanisms that cause partisan interests to trump, or be trumped by, institutional interests are manifold and highly contextual. $^{88}$ For our purposes, the only necessary point is that constitutional showdowns occur under unified as well as divided government. In the Youngstown case, ${ }^{89}$ which clarified the limits of presidential power, the Democratic party held the presidency, large majorities in Congress, and a large majority on the Supreme Court. A constitutional showdown occurred nonetheless, out of a mix of institutional conflicts and personal animosities among the main actors. As Youngstown illustrates, showdowns under unified government may be purer cases than under divided government: common partisan affiliation ensures, or is at least correlated with, common policy preferences, so the only dispute is over the allocation of authority (as in cell (2), in Table 1 above).

Overall, it is unclear whether showdowns are more or less likely under unified or divided government, or whether they have the same characteristics when they do occur under either political condition. The most that can be said is that while partisan animosity in divided government adds some uncertain probability of conflict between branches, the tendency under unified government to commonality of preferences across branches clarifies that showdowns are indeed over authority, not policy. If fewer showdowns occur under unified government, the ones that do occur are thus more consequential for the allocation of powers.

One might speculate that because political parties know that they will, roughly, alternate control of the various lawmaking institutions, something like the symmetry of interests needed for the emergence of

${ }^{87}$ Vermeule, supra note 3 , at 1161-66.

${ }^{88}$ For some suggestions about mechanisms that cause individuals to internalize the interests of institutions, see Jon Elster, The Role of Institutional Interest in East European Constitution-Making, E. EUR. CONST. REV., Winter 1996, at 63.

${ }^{89}$ Youngstown Sheet \& Tube Co. v. Sawyer, 343 U.S. 579 (1952). 
efficient customs is present. The party temporarily in control of the presidency knows that strengthening the presidency to excess today will harm the party's interests when it controls (only) the legislature tomorrow. However, this hardly guarantees the emergence of efficient customs or norms. Because the system is a complicated and contingent mix of separated parties and separated powers, parties lack the full capacity to produce welfare-maximizing customs even if they would wish to do so. Partisan interests will regularly-but unpredictably-be subordinated to institutional and personal interests, and this will hamper the partisan cooperation needed to produce efficient customs (even assuming that the necessary symmetry of partisan interests obtains).

\section{Illustrations}

Given this analysis of the divergence between private and social costs and benefits, we should expect to find that the following conditions characterize structural constitutional law: First, there is a great deal of uncertainty about the allocation of powers across institutions, because current institutions do not fully internalize the social benefits of creating clarifying precedents through showdowns. Second, where clear precedents are set, they are at least sometimes premature or unnecessary, because institutions engage in showdowns even if it would be socially optimal to set the precedent later, with more information, or not at all, because the issue will not be repeated in the future. Third, where institutions engage in showdowns, they sometimes succeed in setting bad precedents that undermine the separation of powers system through aggrandizement-defining aggrandizement by reference to some benchmark of the optimal separation of powers.

There are, of course, pockets of structural constitutional law in which none of these conditions hold. But nothing in the separation of powers system guarantees they will not; nothing systematically works in favor of optimal precedent-setting. We do not provide a comprehensive review, but offer some suggestive illustrations.

\section{Uncertainty}

Descriptively, American separation of powers law is blanketed by the fog of uncertainty. In every subfield, major questions go unresolved, generation after generation, because the institutions of any given generation avoid the showdowns that would clarify the constitutional allocation. Consider some well-known examples. It is still unclear whether Congress can preclude judicial review of constitutional 
questions or strip the Supreme Court of jurisdiction in defined categories of cases, especially cases bearing on constitutional rights. Broadly speaking, the reason is that the Court avoids the question through statutory construction, and Congress does not force the issue.

In foreign relations and national security law, the constitutional allocation of war powers is unsettled to this day in crucial respects. Although historical and judicial precedents have settled some controversies-for example, that the President has inherent authority to use military force even if he is not repelling a sudden attack, and that the President cannot seize domestic industries necessary to a war effort, at least not if Congress has impliedly prohibited him from doing somany crucial questions remain unclear. Topically, there are controversies about whether Congress may, by statute, prohibit President Bush from deploying troops in Iraq, ${ }^{90}$ and about whether repeal of the 2003 statute authorizing deployment of troops will force the President to withdraw. It is astonishing to nonlawyers that there is no definitive answer about what legal validity and effect these measures would have. Here too, the reason is that in generation after generation decisive clarification is avoided by conflict-averse institutions.

Nothing in our discussion indicates that this level of uncertainty is higher than optimal. However, given that uncertainty is a cost, all else equal, the massive levels of uncertainty in structural constitutional law would have to provide massive collateral benefits to be justifiedbenefits that could not be provided more cheaply through other mechanisms. No one has convincingly identified any such benefits, or explained why high levels of uncertainty are necessary to produce them.

\section{Unnecessary Precedents}

Are there unnecessary precedents-again, defined as precedents whose costs of generation are greater than their direct plus indirect benefits in settling future controversies-in structural constitutional law? Consider the early controversies over the federal government's Commerce Clause authority to build and operate "internal improvements," or public goods involving infrastructure and transportation. Although such improvements have not been controversial since the

${ }^{90}$ See Exercising Congress's Constitutional Power To End a War: Hearing Before the $S$. Comm. on the Judiciary, 110th Cong. (2007) (statement of David J. Barron, Professor of Law, Harvard Law School), available at http://www.law.harvard.edu/news/2007/01/ Barron\%20Testimony.pdf ("In my judgment, proposals ... to bring the deployment itself to an end through curtailment of funds fall well within [Congress's] authority."). 
early to mid-nineteenth century, the relevant legislative and judicial precedents have shaped the later development of Commerce Clause doctrine. ${ }^{91}$ This is plausibly a case in which $D$, the direct value of precedent for future generations, was low while $I$, the indirect value, was high. Given the high costs of the political conflicts surrounding internal improvements $C$, perhaps $C$ was greater than $D+I$. A problem with this example, however, is that it is not clear that the disappearance of the issue was exogenous to the setting of the precedents: perhaps the issue disappeared only because the federal government was found to be authorized to create the improvements and did so.

For a somewhat less ambiguous example, consider the Thirteenth Amendment. As David Strauss emphasizes, the Civil War, not the Thirteenth Amendment, likely ended slavery: "The most that can be said for the Thirteenth Amendment is that it hastened the end of slavery in a few border states by a few years." ${ }^{92}$ This, then, is a case where $D$ was quite low; and $I$ also seems low, given that the Amendment has not been a major source of constitutional analogies and principles in later controversies. ${ }^{93}$ What makes the example slightly ambiguous, nonetheless, is that the marginal cost of producing the Amendment, over and above the cost of fighting the Civil War itself, was itself low as well.

The paucity of really clean examples in this category suggests a political mechanism that may check the creation of unnecessary precedents: politicians, including judges, will generally be loathe to engage in genuinely optional showdowns. Rather, they will focus only on disputes that circumstances force onto the political agenda. (Because of the private incentive to duck even those disputes, some crucial issues will be left shrouded in uncertainty and punted to the future, even if it would be socially optimal to resolve them now.) If that is so, then departures from optimality are likely to occur in the direction of too few

${ }^{91}$ See generally Adam S. Grace, From the Lighthouses: How the First Federal Internal Improvement Projects Created Precedent that Broadened the Commerce Clause, Shrunk the Takings Clause, and Affected Early Nineteenth Century Constitutional Debate, 68 ALB. L. REV. 97 (2004) (analyzing the development of federal law regarding infrastructure).

${ }^{92}$ David A. Strauss, The Irrelevance of Constitutional Amendments, 114 HARV. L. REV. $1457,1480-81$ (2001).

${ }^{99}$ When scholars invoke Thirteenth Amendment principles, the arguments are typically dismissed as excessively ingenious. Compare Akhil Reed Amar \& Daniel Widawsky, Child Abuse as Slavery: A Thirteenth Amendment Response to DeShaney, 105 HARV. L. REV. 1359 (1992) (analogizing child abuse to slavery and invoking the Thirteenth Amendment), with RICHARD A. POSNER, OVERCOMING LAW 211-14 (1995) (addressing and dismissing Amar's and Widawsky's Thirteenth Amendment analogy). 
showdowns, but unnecessary showdowns will not be a major problem; excessive uncertainty, rather than premature or unnecessary clarity, will be the result.

\section{Showdowns and Aggrandizement}

It is difficult to give evidence that showdowns can produce (not just prevent) aggrandizement, because there is no consensus on a normative benchmark. However, it can be shown more narrowly that relative to a wide range of such benchmarks, aggrandizing showdowns occur. Commentators who have very different accounts of the optimal distribution of powers across institutions have in common the belief that, relative to their own preferred accounts of the optimal distribution of powers, showdowns have produced aggrandizement. Consider Robert Bork's view that the Supreme Court's power grew alarmingly after it largely prevailed in the criminal procedure showdowns of the 1960s, while Richard Epstein holds that the power of the President and Congress grew alarmingly when they prevailed over the Old Court in the constitutional showdowns of the late 1930s. Bork and Epstein have very different views about the optimal distribution of powers, but both agree that the showdowns to which they point produced a maldistribution of powers relative to their preferred benchmarks.

\section{IMPLICATIONS}

What recommendations flow from this analysis, if any? It is hard to say anything very crisp in the abstract, because many of the relevant empirical and causal questions remain unsettled. However, we will highlight some possible counterintuitive implications of the analysis that hold under plausible conditions. Section A critiques the passive virtues, while Section B puts our claims in the context of some standard controversies in legal and constitutional theory.

\section{A. The Active Virtues?}

The major implication is that under certain conditions the active virtues, the embrace of clarifying conflict, should be preferred to the passive virtues, or the evasion of unnecessary conflict. The passive virtues, which we have summarized in Part II, encourage institutionsespecially courts-to avoid unnecessary constitutional conflicts. As against the passive virtues, however, decisive constitutional conflicts and precedent-setting showdowns should actually be encouraged 
where the value of waiting for more information is low, where similar issues will frequently recur in future generations (so that the value of settling questions now is high), and where legal uncertainty will impose high costs in the future. In general, theorists of the passive virtues focus to excess on option value and the benefits of avoiding conflict, while ignoring the opportunity cost of failures to clarify the constitutional rules in ways that can avoid more conflict in the future. The theorists sometimes talk as though conflict can simply be avoided altogether. In some domains, however, there is an intertemporal tradeoff: less institutional conflict now guarantees more institutional conflict over time. Where aggregate future conflict, even properly discounted, imposes greater social costs than present conflict, and present conflict would avoid future conflict, a showdown in the current period would be socially beneficial.

On this view, a major problem with standard accounts of the passive virtues is that they tend to take into account only the costs and benefits to the relevant institution, usually the judiciary, rather than overall social costs and benefits. This is usually implicit: in the judicial context, consider Justice Brandeis's famous formulation, which summarized various legal techniques for avoiding "unnecessary" constitutional questions and confrontations as rules the Court has "developed[] for its own governance in the cases confessedly within its jurisdiction." ${ }^{94}$ The main thrust of Brandeis's discussion, and of some of Brandeis's later exegeses, is that the Court's institutional position and prestige benefit by avoiding showdowns. But, as we have emphasized, the social costs and benefits of avoiding or engaging in showdowns are different than the private or institutional costs and benefits.

Theorists of the passive virtues sometimes say, or implicitly suggest, that what benefits the courts also benefits the overall system of separation of powers: what is good for the Court is good for the country. Thus in the judicial setting, the passive virtues can be defended as a device for husbanding the judiciary's prestige over the long run, enabling it to defend individual rights or to enforce the rule of law in times of great crisis. ${ }^{95}$ It is unclear whether this indirect account of social benefits has had much motivating power for the judges, as com-

${ }^{94}$ Ashwander v. Tenn. Valley Auth., 297 U.S. 288, 346-48 (1936) (Brandeis, J., concurring).

${ }^{95}$ See GEYH, supra note 17 , at 224-43 (discussing methods of judicial avoidance and providing examples); $c f$. JESSE H. CHOPER, JUDICIAL REVIEW AND THE NATIONAL POLITICAL PROCESS 129-70 (1980) (arguing that the Supreme Court should preserve its institutional capital by avoiding questions of federalism or separation of powers). 
pared to the short-run benefits to the Court itself of avoiding constitutional showdowns when in a position of weakness, but let us suppose that it has been motivational. Still, the social benefit of preserving the Court's long-run prestige captures only one side of the social ledger. The other side of the ledger includes the social cost of legal uncertainty and the conflict it breeds in future periods.

It is conceptually possible that, even if the Court's interests and the nation's interests diverge in some range of cases, it is nonetheless good for the nation to have Justices who think that what is good for the Court is also good for the nation. The implicit theory would be one of Madisonian competition. Even if the first-best is to have officials in all institutions who act for the public interest, the attainable second-best might be to have officials in all institutions who act for the interests of their institutions, thus producing a kind of equilibrium convergence on the public interest.

But as we have argued, Madisonian "competition" rests on a false analogy to markets. In the separation of powers system, there is no invisible-hand mechanism that systematically aligns the decentralized pursuit of institutional interests with social welfare or the public good, however those notions are construed. It is not that institutional interests and the nation's interests are systematically opposed, any more than they are systematically aligned. It is that whether they are opposed or aligned is a matter of circumstance, differing across cases; there is no basis for even a presumption that the overall good will be attained by institutions pursuing their interests in a decentralized manner. A system of that sort can result in too few showdowns, too many showdowns, or the wrong types of showdowns at the wrong time.

Under certain conditions, then-where the value of setting precedents now is especially high, because similar issues will recur in future generations and little new information will be gained by delay-the active virtues are superior to the passive virtues from the social point of view. We do not claim that these conditions are more common than the conditions under which the passive virtues are socially desirable. All we claim is that the theorists of the passive virtues systematically fail to consider the full range of social costs and benefits, and are too sanguine about their conflict-avoiding prescriptions. 


\section{B. Controversies in Legal Theory}

\section{Precedent}

One of our themes is that the resolution of conflicts over constitutional authority establishes judicial or nonjudicial precedents that guide the conduct of future agents. There is a direct analogy in the practice of common law courts, which similarly resolve disputes that establish precedents that guide future courts faced with similar disputes. When courts resolve disputes, they frequently resolve unsettled questions about jurisdiction-which court has authority over the dispute-and questions about the authority of other government institutions. Courts tend to respect earlier courts' decisions about both questions even though there is no external force that could sanction courts for failing to do so.

Many scholars have provided explanations for this phenomenon. Typically, they rely on repeated game ideas, where an agent who fails to respect a precedent will find that its own precedents are not respected in the future. ${ }^{96}$ Our purpose here is not to apply these ideas directly to the problem at hand, but just to point out that our problem is one of a general class that has received a great deal of attention in the literature. This is the problem of how institutions (or people) maintain their respective roles in the absence of an external power that can sanction them from overstepping the limits of their authority. Much constitutional scholarship assumes that the judiciary is this external power, but, as should be clear from our discussion, we do not think that courts can serve this role. Instead, they are simply one of several agents that maintain their power in part by limiting their ambitions and in part by challenging other institutions that attempt to enforce a limited rather than expansive judicial role.

What we have called ambiguous acquiescence also has an analogy in the common law practices of courts. Sometimes, courts decide cases on alternative grounds, which weakens the precedential effect of the decision. In addition, courts will often decide cases without issuing reasoned opinions or decide cases with opinions that are deemed nonprecedential. Not all of these strategies have the same effect, but in general they can be thought of as situations where courts economize on decision costs and so come to outcomes that they believe should pro-

${ }^{96}$ See, e.g., Eric Rasmusen, Judicial Legitimacy as a Repeated Game, 10 J.L. ECON. \& ORG. 63 (1994) (developing a game-theoretic model of judicial legitimacy). 
vide minimal guidance for future courts. Such a strategy is most warranted when the issues raised by the dispute are unlikely to recur.

\section{Evolving Constitutions and Constitutional Moments}

Much constitutional law scholarship concerns the nature of constitutional development or evolution. Textualists and originalists believe that the Constitution changes only through amendment, but this view is best taken as a normative argument. Few people dispute that the meaning of the Constitution has changed a great deal since the founding. Judicial precedents provide the obvious examples, but the working out of authority between the executive and legislative branches, and between the national and state governments, is equally important, although the documentary record is less clear.

How does the Constitution change, as a positive matter, if the formal amendment procedure is not used? One view draws on the analogy to common law development. Judges interpret constitutional provisions in light of new conditions not anticipated by the founders, in doing so subtly (and sometimes not so subtly) changing its meaning. Over time, these interpretations accrete and yield new allocations of power. ${ }^{97}$ Another view finds constitutional change in moments of upheaval when the public is supposedly attuned to politics and constitutional issues to a greater extent than in normal times. The Civil War and the New Deal are cited as examples. The public approves of changes in higher law, and these changes are duly respected by political actors. ${ }^{98}$

The implicit picture on which we rely is neither as judge-centered as the first account nor as episodic as the second: constitutional showdowns occur regularly, but the most frequent and important cases occur outside the courts. We think of constitutional change as a routine phenomenon that political actors have a special role in provoking. Public constitutional sentiment evolves in subterranean fashion, generally unperceived by those who exercise power. However, when political agents disagree about the allocation of authority, they must make predictions about how the public will react if a showdown occurs. The agents subtly shift their allocation claims in response

${ }^{97}$ See David A. Strauss, Common Law Constitutional Interpretation, 63 U. CHI. L. REV. 877, 884-91 (1996) (describing constitutional change as a common law process).

${ }^{98}$ See 2 BRUCE ACKERMAN, WE THE PEOPLE 3-31 (1998) (examining higher lawmaking generally); ACKERMAN, supra note 4, at 266-69 (considering higher lawmaking in the context of the New Deal). 
both to their predictions about public reaction and to the clarifying effects of showdowns when they actually occur.

We said that our positive picture of constitutional development is inconsistent with originalism. However, it is plausibly consistent with (a suitably specified version of) popular constitutionalism, although the sponginess of the latter approach makes it hard to be sure. Some "popular" constitutionalists seem to envision widespread and genuinely inclusive debate over constitutional meaning, ${ }^{99}$ while others tend to focus on political movements among the educated and other elites. $^{100}$ In our approach, the elites who control the institutions of government effectively decide whether or not to engage in precedentsetting showdowns, but public constitutional sentiment-which may or may not be very popular, depending on circumstances-is both a major political constraint and a major variable in the elites' political calculations. The populace at large exercises an indirect influence over constitutional development, but as a filter that rules out certain elite positions and as an ultimate court of appeal, rather than as a front-line participant.

\section{Judicial Review and Deference}

The positive claim that constitutional development occurs through precedent-generating showdowns and the normative claim that the judiciary and other institutions will produce social benefits by embracing the active virtues under identifiable conditions both cut across standard controversies about judicial review of legislation and executive action for constitutionality. Nothing in the idea of a precedent-generating showdown, or in our prescription for the active virtues, requires aggressive judicial review on the merits; to think so is to confuse legal certainty or clarification with the content of the legal rules. A showdown that decisively clarifies the power of the Supreme Court in a certain domain might produce expansive judicial power, or instead a great deal of judicial deference-perhaps something like James Bradley Thayer's rule that courts would overturn legislation on constitutional grounds only when the legislature has made a "clear

99 See generally LaRry D. Kramer, The People Themselves: POPUlar ConstituTIONALISM AND JUDICIAL REVIEW (2004).

${ }^{100}$ See Robert C. Post \& Reva B. Siegel, Protecting the Constitution from the People: Juricentric Restrictions on Section Five Power, 78 IND. L.J. 1 (2003) (addressing the Rehnquist Court's assumption of authority over constitutional questions that would otherwise be entrusted to Congress). 
mistake" about constitutionality. ${ }^{101}$ Thus showdowns over social and economic regulation in the 1930s clarified that the Court would take a Thayerian, highly deferential approach to review under the Commerce Clause ${ }^{102}$ and would essentially cease enforcing the so-called "nondelegation doctrine." ${ }^{109}$ Bracketing the intensity of judicial review, which might be low or high on the merits, the positive benefit of clarification for future generations is the same.

Conversely, neither the passive virtues nor minimalism have any necessary connection to the intensity of judicial review. The passive virtues can be used to avoid backlash against intrusive constitutional decisions and to harbor judicial capital for aggressive judicial review in a future period, as when the Warren Court ducked the inflammatory issue of the constitutionality of antimiscegenation laws. ${ }^{104}$ On the other hand, the passive virtues can instead be used as part of a longterm practice that cuts the judiciary out of certain questions, leaving in place whatever status quo arrangements legislators and the President have worked out. An example of the latter form of the passive virtues, discussed above, is the long-term judicial practice of ducking questions about the constitutional allocation of war powers. So too with minimalism: narrow and shallow decisions can be deferential to government on the merits, or not deferential. The issue of deference is orthogonal to the question of whether constitutional decisions should be minimalist or maximalist.

\section{CONCLUSION}

Good lawyers advise their clients to settle because litigation is a costly and risky process, and clients frequently overestimate the gains and underestimate the costs. But in the constitutional setting, where the choice is between settlement and showdown, rather than settlement and trial, the costs and benefits are not the same. Settlements avoid diversion of the government's energy away from the problem at hand, but the showdown is an important engine of constitutional de-

${ }^{101}$ See James B. Thayer, The Origin and Scope of the American Doctrine of Constitutional Law, 7 HARV. L. REv. 129, 144 (1893) (arguing that judicial review should use a "clear mistake" standard).

${ }^{102}$ See NLRB v. Jones \& Laughlin Steel Corp., 301 U.S. 1, 49 (1937) (holding that farreaching federal regulation of industry is within Congress's Commerce Clause power).

${ }^{103}$ See Lichter v. United States, 334 U.S. 742, 785 (1948) (allowing Congress to grant substantial discretion to officials).

${ }^{104}$ See Naim v. Naim, 350 U.S. 891, 891 (1955) (refusing to consider the merits because of an inadequate record). 
velopment, and sometimes the only way to realign institutional lines of authority with public sentiment is through confrontation. In the case of public law, as with some types of public-law litigation, confrontation benefits third parties and future generations by clarifying the rules of the game. ${ }^{105}$ Well-motivated constitutional actors in the present will take this benefit into account.

${ }^{105}$ Cf. Fiss, supra note 66 (discussing the costs of settlement to third parties who are deprived of useful precedents). 